HETEROCYCLES, Vol. , No. , , pp. -. (c) The Japan Institute of Heterocyclic Chemistry

Received, , Accepted, ,Published online, . COM-06- (Please do not delete.)

\title{
ORGANOCATALYTIC ASYMMETRIC SYNTHESIS USING PROLINE AND RELATED MOLECULES. PART 2.
}

\author{
Hiyoshizo Kotsuki, ${ }^{*}$ Hideaki Ikishima, and Atsushi Okuyama \\ Laboratory of Natural Product Chemistry, Faculty of Science, Kochi University, \\ Akebono-cho, Kochi 780-8520, Japan \\ e-mail:kotsuki@kochi-u.ac.jp
}

\begin{abstract}
Organocatalytic asymmetric synthesis has been extensively studied and several important procedures for preparing optically active organic compounds have been developed. Research activities in this area have progressed rapidly in the last ten years. This review addresses the most significant advances in asymmetric synthesis using proline and related chiral organocatalysts, mainly from the viewpoint of synthetic applications. This includes (1) Mannich reactions, (2) Michael addition reactions, (3) $\alpha$-oxidation, (4) $\alpha$-amination, (5) $\alpha$-sulfenylation / selenenylation, (6) $\alpha$-halogenation, (7) cycloaddition reactions, and (8) miscellaneous reactions such as $\mathrm{C}-\mathrm{C}$ bond formation, epoxidation / oxidation, and reduction.
\end{abstract}

\section{MANNICH REACTIONS}

The Mannich reaction is one of the most important multi-component condensation reactions using aldehyde, ketone and amine for the preparation of $\beta$-amino carbonyl compounds. This type of reaction is considered to be analogous to aldol condensation, and hence several approaches using organocatalytic systems have been reported to date. ${ }^{1}$

In 2000, List and coworkers reported the first example of the asymmetric Mannich reaction using L-proline as an organocatalyst. ${ }^{2}$ For example, the reaction of acetone (excess), $p$-nitrobenzaldehyde, and $p$-anisidine in the presence of L-proline (35 mol\%) gave the desired adduct in 50\% yield with $94 \%$ ee (Scheme 1). The proposed mechanism involves the hydrogen-bonding activation mode between the enamine intermediate obtained from acetone and L-proline and the imine substrate in situ generated from $p$-nitrobenzaldehyde and $p$-anisidine. It is plausible that the stereochemistry of the product might be governed by steric repulsion between the anisidine and pyrrolidine moieties in the transition state. ${ }^{3}$ 
<smiles></smiles>

(20 vol\%) (1.1 eq)

(1.0 eq)

$50 \%$ yield, $94 \%$ ee

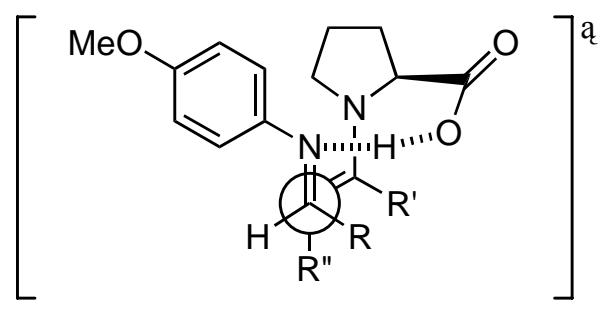

Scheme 1. L-Proline-catalyzed asymmetric Mannich reactions and the proposed transition state

Imines derived from $\alpha$-imino ethyl glyoxylate can act as sufficiently reactive substrates and the method provides an efficient entry to a variety of substituted $\alpha$-amino acid derivatives (Scheme 2). ${ }^{4,5}$

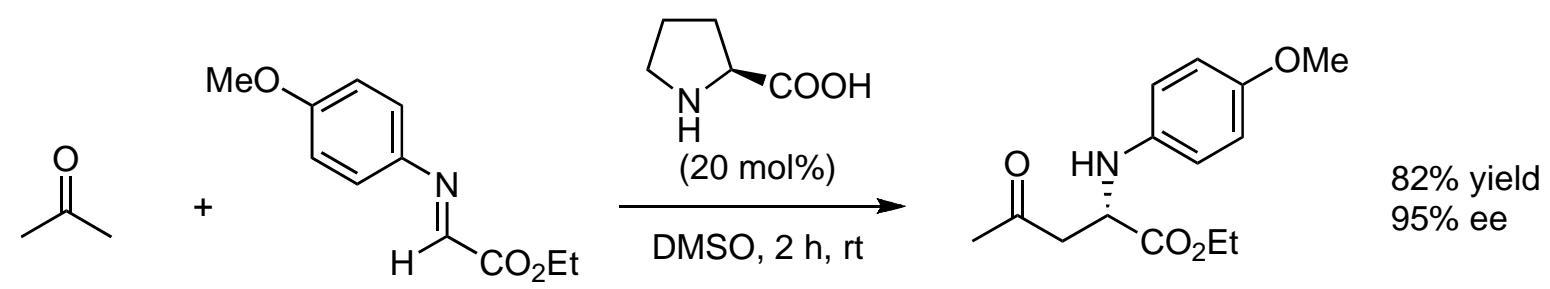

Scheme 2. L-Proline-catalyzed asymmetric Mannich reactions using a glyoxylate substrate

Barbas III, ${ }^{4 \mathrm{~g}}$ Córdova $^{6}$ and Hayashi ${ }^{7}$ have established independently that proline-catalyzed reactions are valuable for performing cross-Mannich reactions using two different kinds of aldehydes with amines (Scheme 3). Application of this chemistry to the concise synthesis of nitrogen-heterocycles has also been reported. ${ }^{8}$

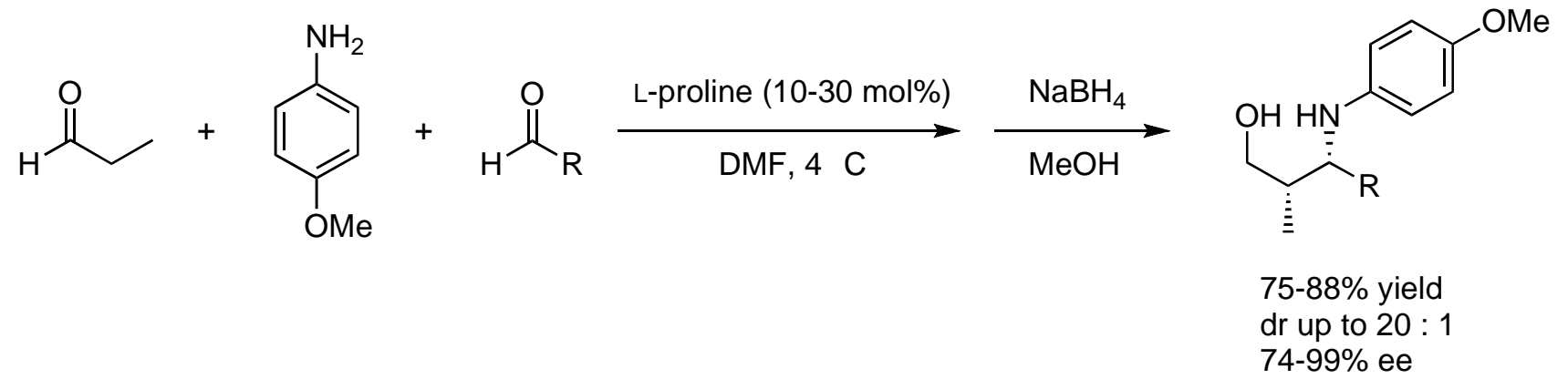

Scheme 3. L-Proline-catalyzed asymmetric cross-Mannich reactions 
The synthetic utility of proline-catalyzed Mannich reactions has been widely established by the construction of a variety of compounds, including aminosugar derivatives, in conjunction with other methods of forming $\mathrm{C}-\mathrm{C}$ bonds such as cyanation, allylation, and Wittig olefination (Scheme 4). ${ }^{9-11}$

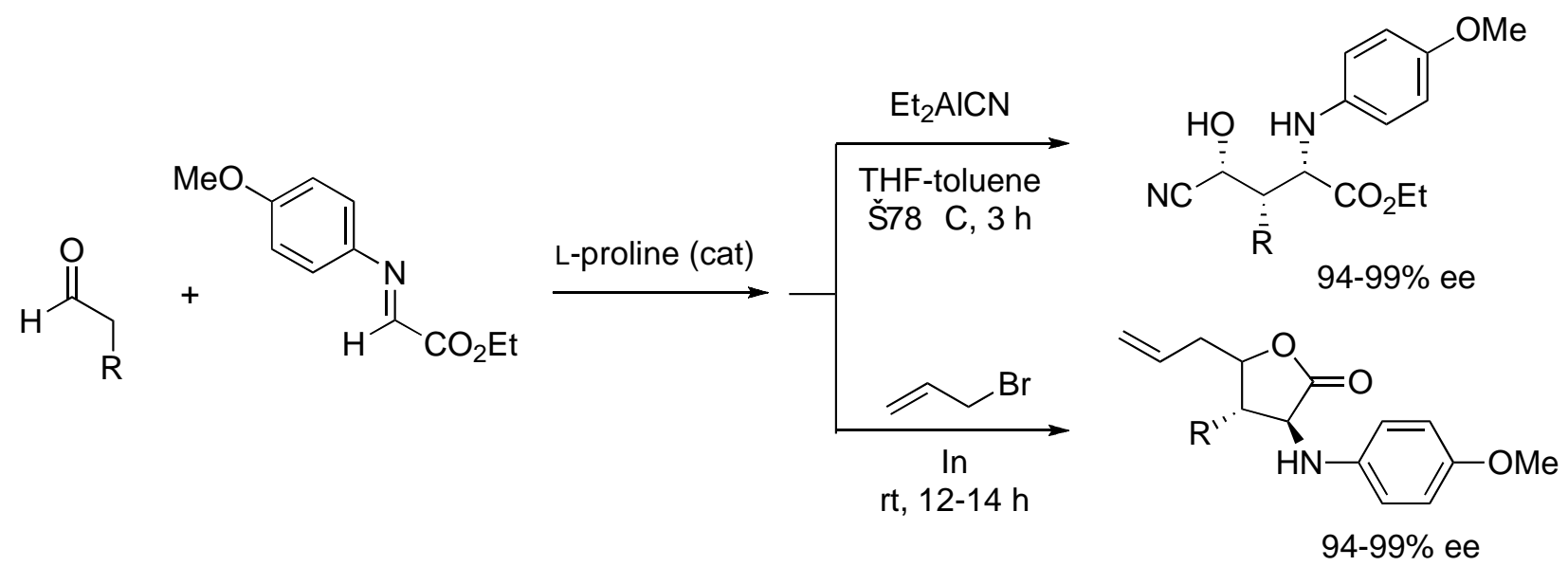

Scheme 4. Tandem use of Mannich reactions with cyanation ${ }^{4 \mathrm{c}}$ and allylation ${ }^{4 \mathrm{~d}}$

The proline-catalyzed Mannich reaction is generally successful for aldehydes bearing an electron-withdrawing functionality as acceptors. For less-reactive substrates, the use of pressure, microwave, and ultrasonic techniques has been found to be useful. ${ }^{12-14}$ From an environment-friendly viewpoint, the use of water or an ionic liquid as novel reaction media and in some cases the incorporation of a proline catalyst core to a polymer support might be also effective. ${ }^{4 \mathrm{~d}, 15,16}$

The chirality of the proline core plays a critical role in the design of new organocatalysts, and some representative examples of such catalysts are shown in Chart $1 .{ }^{17-25}$ In addition, typical examples of its application to asymmetric Mannich reactions are illustrated in Schemes 5-7.

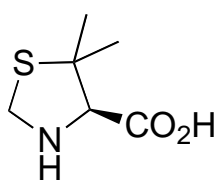

1

TBSO

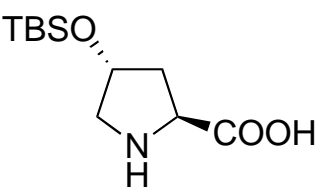

6

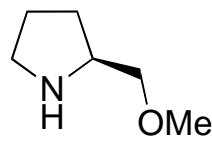

2

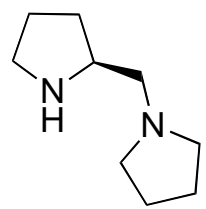

7

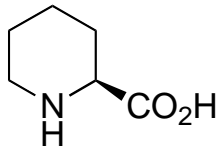

3

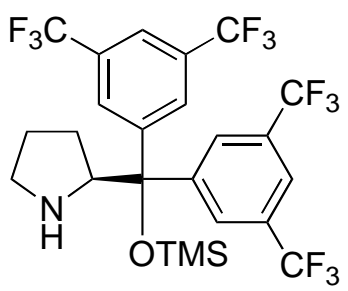

8

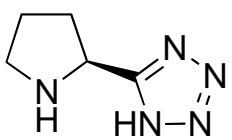

4

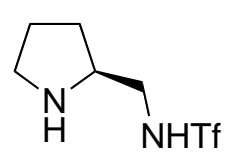

9

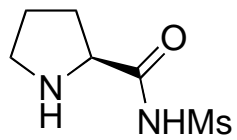

5

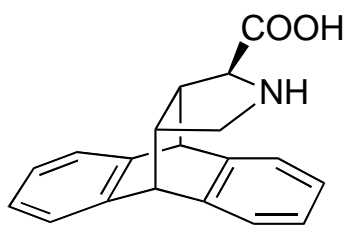

10

Chart 1. Representative examples of proline-related organocatalysts 
<smiles>CCOC(=O)/C=N/c1ccc(OC)cc1</smiles><smiles>CCOC(=O)[C@H]1CCCCC1=O</smiles>

$70 \%$ yield

$\mathrm{dr}>19: 1$ ee $>99 \%$

Scheme 5. Asymmetric Mannich reactions catalyzed by $4^{18 \mathrm{a}}$<smiles>[R]CC(=O)C[R]</smiles><smiles>CCOC(=Nc1ccc(OC)cc1)OCC</smiles><smiles></smiles><smiles>[R1]CC(=O)C([R2])[C@H](Nc1ccc(OC)cc1)C(=O)OCC</smiles><smiles>CCOC(=O)[C@H](NNC(=O)O)[C@@H](C)C(C)=O</smiles>

$84 \%$ yield ee $=97 \%$ $\mathrm{dr}>95: 5$<smiles>CCOC(=O)[C@H](NNC(=O)O)[C@@H](C)C(=O)CC</smiles>

$83 \%$ yield ee $=97 \%$ $\mathrm{dr}>95: 5$<smiles>CCOC(=O)[C@H](O)[C@@H](NNC(=O)O)C(C)=O</smiles>

$74 \%$ yield ee $>99 \%$ $\mathrm{dr}>95: 5$

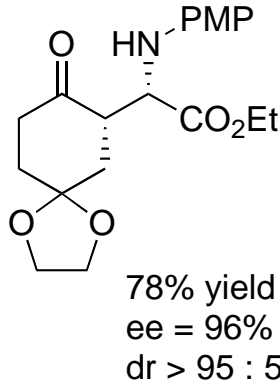

Scheme 6. Asymmetric Mannich reactions catalyzed by $\mathbf{9}^{23}$<smiles>[R]CC(C)=O</smiles><smiles>COc1ccc(N)cc1</smiles><smiles>[R]C=O</smiles><smiles></smiles><smiles>[R]C([R])C(C)=O</smiles>

yield up to $76 \%$ ee up to $90 \%$

Scheme 7. Asymmetric Mannich reactions catalyzed by $\mathbf{1 0}^{24}$

As analogous systems, the use of acyclic amine catalysts such as L-alanine and its tetrazole homolog for Mannich reactions of this type showed high levels of reactivity (up to $90 \%$ yield), diastereoselectivity ( $\mathrm{dr}$ up to $>19: 1$ ), and enantioselectivity (up to $99 \%$ ee) (Scheme 8 ). ${ }^{26}$

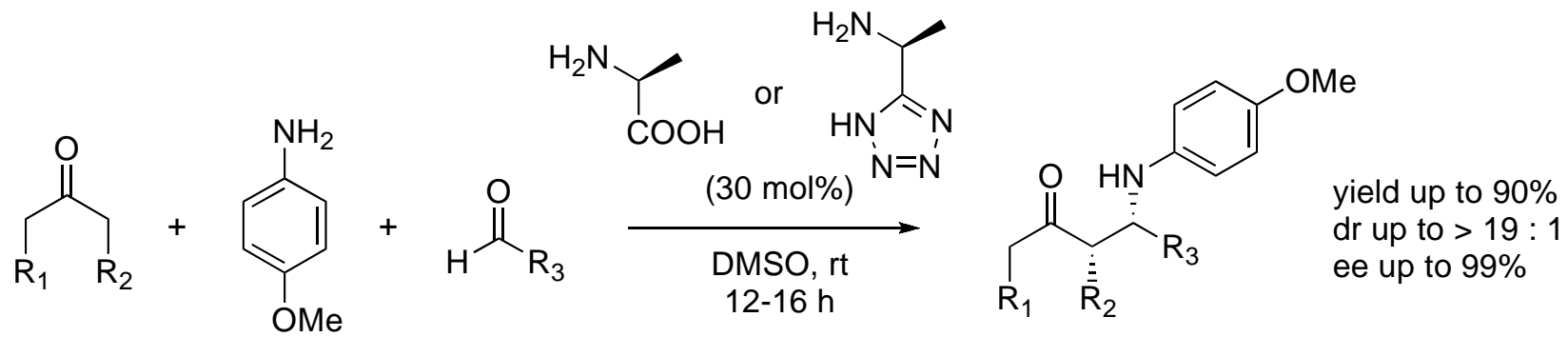

Scheme 8. Asymmetric Mannich reactions catalyzed by acyclic amines ${ }^{26 \mathrm{~b}}$ 
The stereochemical outcome of the proline-catalyzed asymmetric Mannich reaction is usually syn-selective, since the si-face attack on the imine substrate is a highly favorable process, as shown in Scheme 1. On the other hand, considerable attention has recently been focused on the development of anti-selective transformations (Scheme 9).<smiles></smiles>

11

ee up to $99 \%$ dr up to anti : syn $=98: 2$<smiles>CCOC(=O)/C=N/c1ccc(C)cc1</smiles><smiles>CCCCC</smiles><smiles>C[C@H]1CC(C(=O)O)CN1</smiles>

12<smiles>[R]C(C=O)[C@H](Nc1ccc(OC)cc1)C(=O)OCC</smiles><smiles>COC(c1ccccc1)(c1ccccc1)C1CCCN1</smiles>

13

ee up to $>99 \%$

dr up to anti : syn = > 19: 1

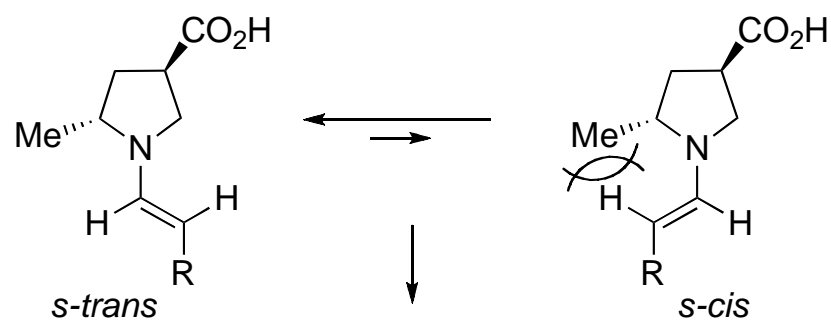

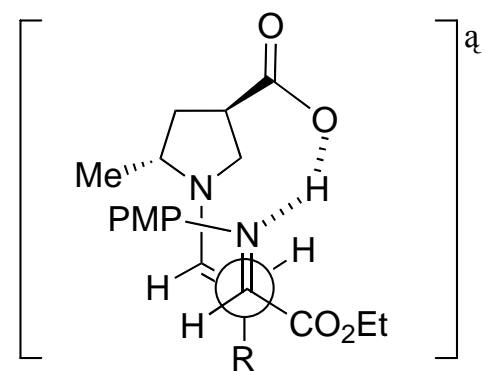

Scheme 9. anti-Selective asymmetric Mannich reactions and the proposed transition state

For example, Maruoka and coworkers reported that the axially chiral amino sulfonamide catalyst $\mathbf{1 1}$ showed efficient catalytic activity with high anti-selectivity (anti / syn = up to $98: 2$ ). ${ }^{27}$ Barbas III (cat 12) and Córdova (cat 13) derived similar conclusions based on their own molecular design of the catalysts. $^{28,29}$ The observed high anti-selectivity can be explained by assuming the formation of the enamine intermediate, in which the less steric repulsion between the methyl group on the proline core and the vinyl proton on the enamine double bond in the s-trans conformation is favorable compared with the corresponding s-cis conformation. 
Very recently, Mauksch and coworkers reported a novel asymmetric autocatalytic system by virtue of specific product-substrate interactions in asymmetric Mannich reactions. ${ }^{30}$

\section{MICHAEL ADDITION REACTIONS}

The Michael addition reaction is one of the most important $\mathrm{C}-\mathrm{C}$ bond-forming reactions in organic synthesis, and enormous numbers of papers on organocatalytic asymmetric transformations are published each year. $^{1 \mathrm{a}, 1 \mathrm{c}, 31}$ In general, amine-catalyzed Michael addition reactions can be classified into three modes of activation (Scheme 10): activation of the Michael acceptor via the formation of an iminium ion species (Type I), activation of the Michael donor via the formation of an enolate ion intermediate which reacts with the acceptor (Type II), and, finally, activation of the carbonyl donor via the formation of an enamine intermediate (Type III).<smiles>[R]C(C=[N+]([R])[R])CN</smiles>

Type I

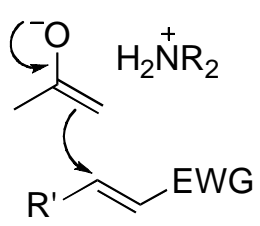

Type II

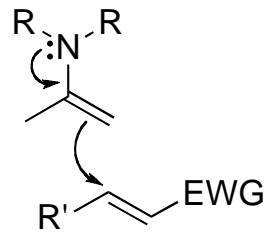

Type III

Scheme 10. Activation modes for amine-catalyzed Michael addition reactions

In 1993, Yamaguchi and coworkers reported a Type I mode of asymmetric Michael addition reactions using an L-proline rubidium salt. ${ }^{32}$ Recently, Hanessian and coworkers found that the asymmetric Michael addition reaction of various nitroalkanes to cyclic enones proceeded with good to high enantioselectivities $(62-93 \%$ ee $)$ in the presence of L-proline as a catalyst and trans-2,5-dimethylpiperazine as an additive (Scheme 11). ${ }^{33}$ The result indicates that the nitroalkane nucleophile attacked the double bond of the in situ formed immonium carboxylate ion intermediate from the less-hindered re-face.<smiles>O=C1C=CCCC1</smiles>

$\mathrm{n}=0,1,2$

$+$

$\mathrm{RR}^{\prime} \mathrm{CHNO}_{2}$<smiles>O=C(O)C1CCCN1</smiles>

(3-7 mol\%)

trans-2,5-dimethylpiperazine $\mathrm{CHCl}_{3}, \mathrm{rt}$<smiles>O=C([O-])C1CCC[N+]1=C1C=CCCC1</smiles>

Scheme 11. L-Proline-catalyzed asymmetric Michael addition reactions 
Other than these examples, there have been only few studies on the direct use of the proline catalyst itself. Instead, the use of proline-based peptides as catalysts (Scheme 12) (34, 35 or the use of active methylene compounds as Michael donors seems to be more feasible (Scheme 13). ${ }^{36-38}$

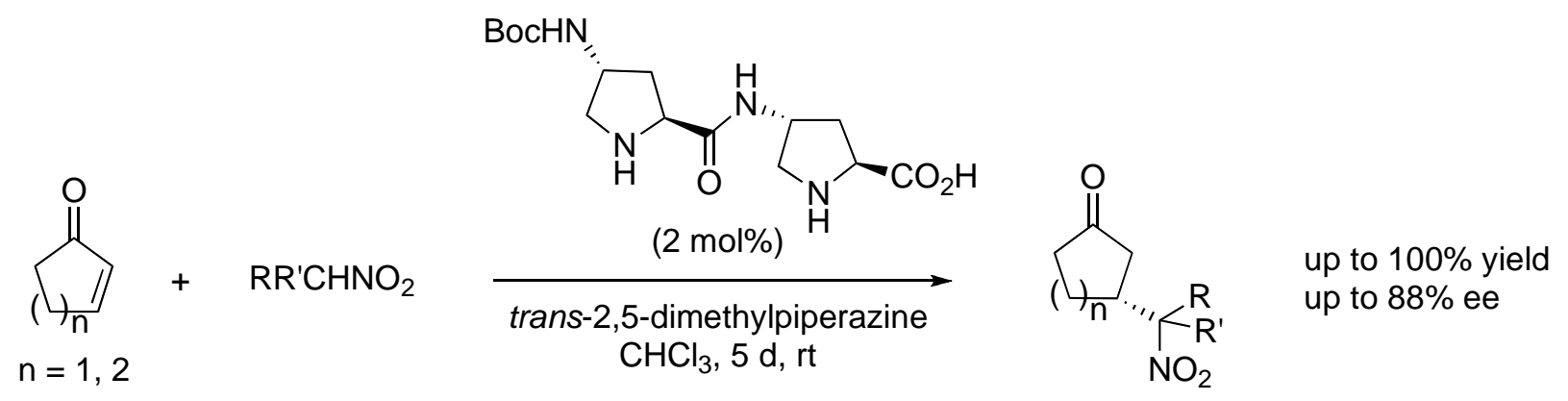

Scheme 12. Asymmetric Michael addition reactions catalyzed by proline-based peptides<smiles>CCOC(=O)CC(=O)OCC</smiles>

(1.0 eq)<smiles>CCOC(=O)CC(=O)OCC</smiles>

(1.0 eq)
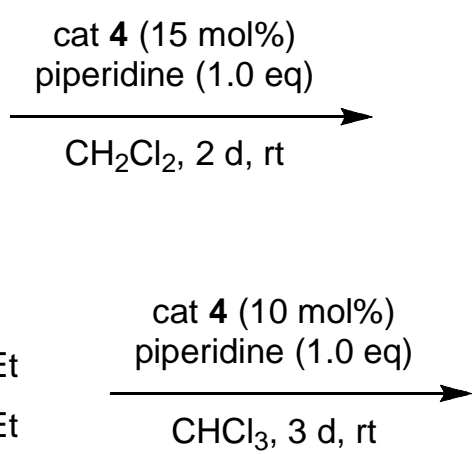<smiles>CCOC(=O)C(C(=O)OCC)[C@H]1CCCC(=O)C1</smiles><smiles>CCOC(=O)C(CC(C)=O)C(CC(C)=O)c1ccccc1</smiles>

$89 \%$ yield $92 \%$ ee

$82 \%$ yield $89 \%$ ee

Scheme 13. Asymmetric Michael addition reactions of malonates to enones ${ }^{38 b}$

The development of new organocatalysts for use in asymmetric Michael addition reactions has now been extensively studied by several research groups. Among them, Ley's tetrazole catalyst $4,{ }^{37}$ Jørgensen's imidazolidine catalysts $\mathbf{1 4 - 1 6},{ }^{39}, 40$ and MacMillan's imidazolidinone catalyst $\mathbf{1 7 ^ { 4 1 }}$, 42 are most representative (Chart 2).<smiles>CN1C[C@H](Cc2ccccc2)N[C@H]1C(=O)O</smiles>

14<smiles>O=C(O)C1N[C@@H](c2ccccc2)[C@H](c2ccccc2)N1</smiles>

15<smiles>CN1CC(Cc2ccccc2)NC1c1nnn[nH]1</smiles>

16<smiles>CN1C(=O)C(Cc2ccccc2)NC1C(C)(C)C</smiles>

17

Chart 2. Representative examples of imidazolidine-based organocatalysts

The synthetic utility of these catalysts can be exemplified in the one-step synthesis of warfarin, an anticoagulant, in an enantiomerically enriched form (Scheme 14), ${ }^{39 c}$ and $\gamma$-butenolide derivatives via the 
Mukaiyama-Michael type addition using silyloxy furans as Michael donors with high enantioselectivities (up to $99 \%$ ee) (Scheme 15). ${ }^{41 \mathrm{a}}$
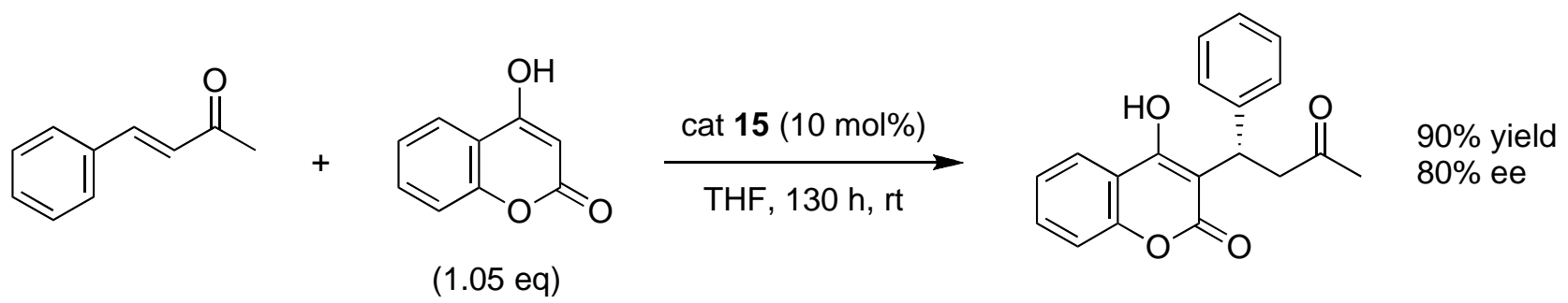

Scheme 14. Asymmetric synthesis of warfarin via organocatalytic Michael addition reaction
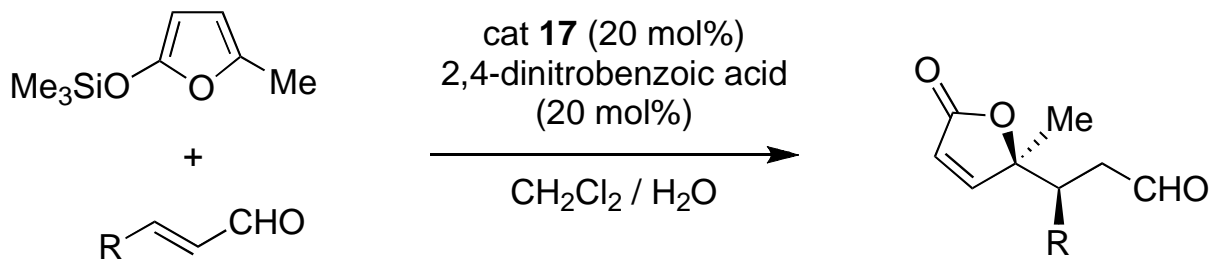

yield up to $87 \%$

syn : anti up to $31: 1$

ee up to $99 \%$

Scheme 15. Asymmetric synthesis of $\gamma$-butenolides via organocatalytic Mukaiyama-Michael reaction

Although there are only a few examples, the 13-related organocatalysts are known to be able to activate the vinylogous-type Michael addition reaction using $\alpha, \beta$-unsaturated aldehydes as acceptors (Scheme $16)^{43,44}$
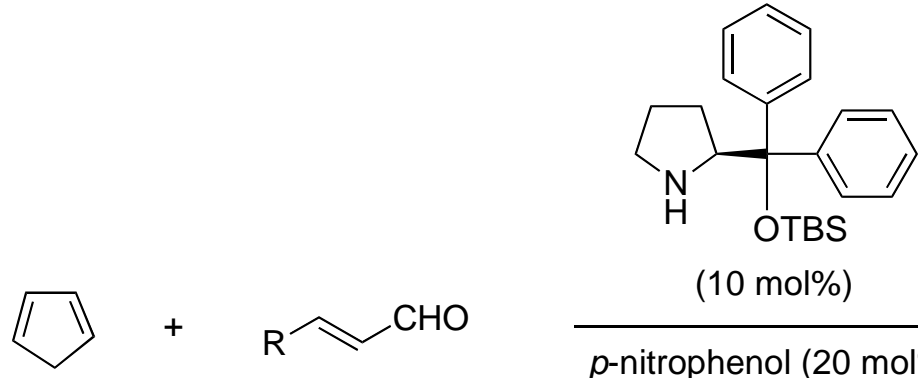

(10 mol\%)

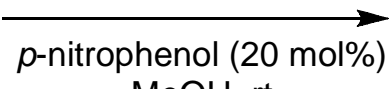

$\mathrm{MeOH}, \mathrm{rt}$<smiles>[R]C(CC=O)C1=CC=CC1</smiles>

yield up to $84 \%$ ee up to $95 \%$

Scheme 16. Asymmetric vinylogous Michael addition reactions of cyclopentadiene ${ }^{44}$

Jørgensen and coworkers reported that a highly concise strategy for enantio- and diastereoselective domino Michael-aldol reactions of $\beta$-ketoesters with $\alpha, \beta$-unsaturated ketones can be performed by catalysis with 14 (Scheme 17). ${ }^{45}$ 


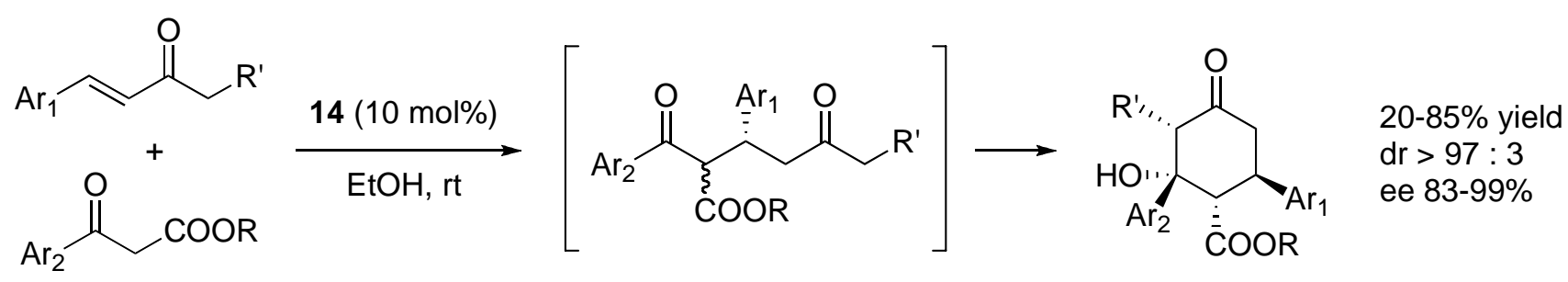

Scheme 17. Diastereoselective domino Michael-aldol reactions catalyzed by $\mathbf{1 4}$

The Type I mode of activation is also generally applicable to the conjugate addition of hetero-atom nucleophiles such as thiols, azide, alcohols, $N$-siloxycarbamates, and aromatic oximes, with excellent enantioselectivities (Scheme 18). ${ }^{46}$ As an extension of this strategy, asymmetric domino Michael-aldol reactions have been developed. ${ }^{47,48}$ This constitutes a convenient way to prepare benzopyran derivatives in enantiomerically pure form (Scheme 19).<smiles></smiles>

$69-92 \%$ yield ee $87-97 \%$

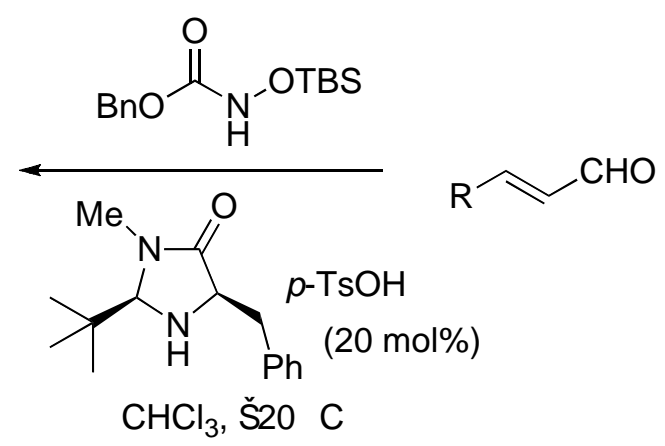

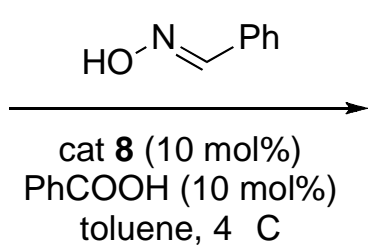

toluene, $4 \mathrm{C}$<smiles>[R]C(CC=O)ON=Cc1ccccc1</smiles>

$60-75 \%$ yield ee $88-97 \%$

Scheme 18. Organocatalytic asymmetric conjugate addition reactions of heteroatom nucleophiles ${ }^{46 e}, 46 \mathrm{f}$<smiles>[X]c1ccccc1C=O</smiles>

Ref. 47a: $X=0$ cat 13 (10 mol\%) in $\mathrm{CH}_{2} \mathrm{Cl}_{2}$, rt up to $70 \%$ yield up to $90 \%$ ee<smiles>[R]C=CC=O</smiles>

cat 8 or 13

Ref. $47 \mathrm{~b}: \mathrm{X}=\mathrm{S}$

cat 8 (10 mol\%) in toluene, rt additive $=\mathrm{PhCOOH}(10 \mathrm{~mol} \%)$ + MS 4A up to $97 \%$ yield up to $95 \%$ ee<smiles>[X]c1ccccc1C=C(C=O)C([R])[X]</smiles>

Ref. 47e: $X=0$ cat $13(20 \mathrm{~mol} \%)$ in toluene, rt additive $=0-\mathrm{NO}_{2} \mathrm{C}_{6} \mathrm{H}_{4} \mathrm{COOH}$ (20 mol\%) up to $95 \%$ yield up to $96 \%$ ee

Scheme 19. Asymmetric synthesis of benzopyran derivatives via organocatalytic domino Michael-aldol reaction

Compared to the Type I mode of activation, the Type III mode opens the door to a remarkably fruitful chemistry.

In 2001, List and coworkers reported for the first time the asymmetric Michael addition reactions of ketones with nitroolefins using L-proline as an organocatalyst, albeit the ee values were only modest (Scheme 20). ${ }^{49}$ Thereafter, Enders and Seki found that when the same reaction was conducted in $\mathrm{MeOH}$, 
diastereoselectivities and enantioselectivities could be improved considerably $(80-97 \%$ de and 7-76\% ee). ${ }^{50}$ On the other hand, the use of $(S)$-homoproline was also found to be successful, as reported by Oriyama and coworkers. ${ }^{51}$ Although the feasibility of the proline-catalyzed asymmetric Michael addition reaction in an ionic liquid as a recyclable reaction medium has been examined, the synthetic value of this process is unclear at present. ${ }^{52}$ In addition, proline-based small peptides and related catalysts were also introduced by List and Córdova. ${ }^{53}$

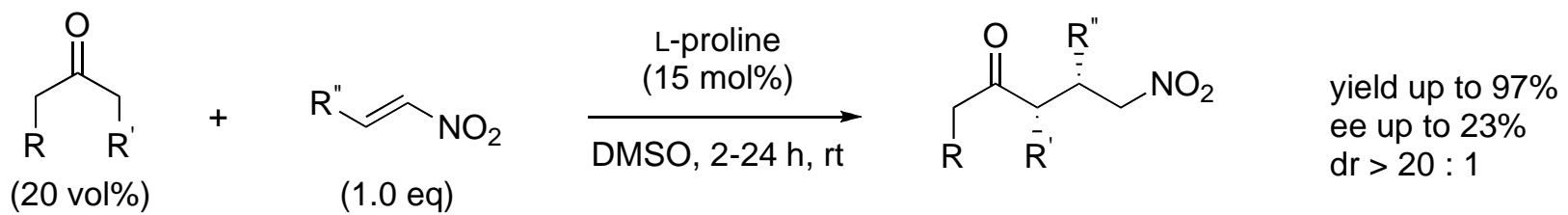

Scheme 20. L-Proline-catalyzed asymmetric Michael addition reactions

In this field, major efforts have been directed to the development of new chiral organocatalysts with a pyrrolidine moiety as a reactive center. Due to the space limitations for this review, we only show representative catalysts $\mathbf{1 8 - 2 8}$, as listed in Chart $3 .^{54-60}$
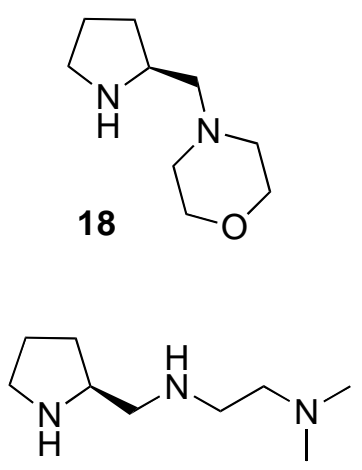

22<smiles>COC(c1ccc(N(CC(F)(F)F)C(F)(F)F)cc1)(c1ccc(C(F)(F)F)cc1)C1CCCN1</smiles>

26
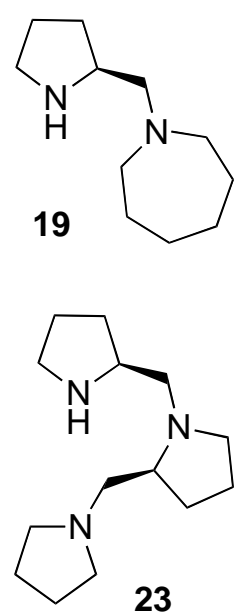

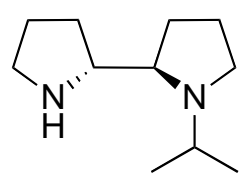

20<smiles>Cc1cc(C)cc(C(c2cc(C)cc(C)c2)C2CCCN2)c1</smiles>

24

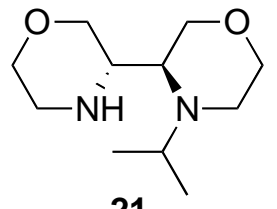

21<smiles>c1ccc([C@@H]2CC[C@H](c3ccccc3)N2)cc1</smiles><smiles>CCC(C)(Oc1ccccc1)c1cc(OCc2ccccc2)cc(OCc2ccccc2)c1</smiles><smiles>c1ccc(-c2cn(CC3CCCN3)nn2)cc1</smiles>

28

Chart 3. Representative examples of pyrrolidine and its related organocatalysts 
In addition to these catalysts, 7 and $\mathbf{8}$ were also found to be effective for the similar type of transformations.

Although there is some controversy regarding organocataysis in aqueous media, ${ }^{61}$ Takabe's recent work is very interesting. ${ }^{62}$ They found that the new diamine catalyst $\mathbf{2 9}$ having a lipophilic alkyl side chain showed a surprisingly powerful catalytic activity in brine as a novel reaction medium (Scheme 21). Thus, the Michael addition reaction of ketones with nitroolefins was efficiently promoted in the presence of 10 mol\% of 29 and an equimolar amount of trifluoroacetic acid in brine, even in seawater, to afford the desired adducts in high yields and high to excellent levels of diastereoselectivity and enantioselectivity (yield up to $99 \%$, dr up to $98: 2$, ee up to $97 \%$ ).

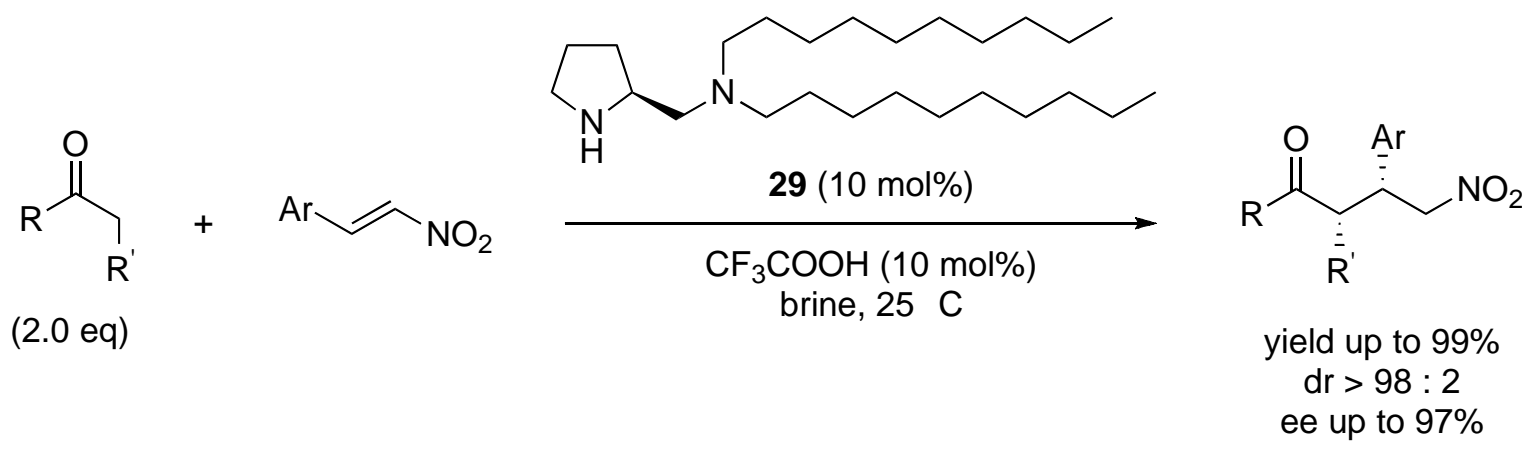

Scheme 21. Diamine 29 TFA-catalyzed asymmetric Michael addition reactions in brine

As in the case of Mannich reactions, the use of new pyrrolidine-heterocycle conjugate catalysts represents a powerful expansion of this field, wherein pyrrolidine-tetrazole catalyst $4^{63}$ and pyrrolidine-triazole catalyst $\mathbf{2 8}^{64}$ have been shown to be useful.

In our research laboratory, we have also been very much interested in devising new catalysts with a pyridine ring as a rigid planar base adjacent to a pyrrolidine chiral ring moiety. ${ }^{65}$ Along this line, three types of catalysts, PYMP (30), DPYMP (31), and PPYMP (32), were prepared from L-prolinol, and we found that $\mathbf{3 1}$ and $\mathbf{3 2}$ possessed excellent catalytic activity in terms of productivity, diastereoselectivity, and enantioselectivity (yield up to $100 \%$, dr up to $>99: 1$, ee up to 99\%) (Scheme 22). The results can be explained by considering an acyclic synclinal transition state model, in which the pyridinium ring must effectively shield the si-face of an enamine double bond.

As additional bifunctional catalysts, chiral amides 33-35, ${ }^{66}$ sulfonamides 9 and $36,{ }^{67}$ thioureas 37 and 39, ${ }^{68}$ and ionic liquid conjugates $\mathbf{4 0}$ and $\mathbf{4 1}{ }^{69}$ are known to be quite effective (Chart 4). In particular, the driving force using the thiourea-type catalyst 37 can be ascribed to the strong hydrogen bond-forming character of thiourea with nitroolefin acceptors, as depicted in transition state 38. On the other hand, the utility of ionic liquid conjugate catalysts $\mathbf{4 0}$ and $\mathbf{4 1}$ can be ascribed to their recyclability. 


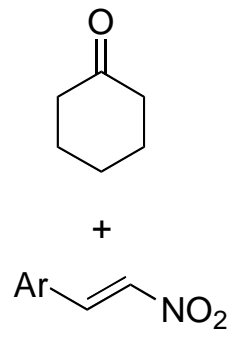

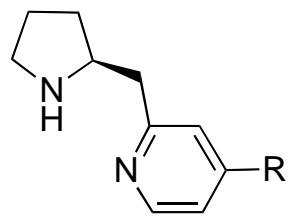

(10 mol\%)

2,4-dinitrobenzenesulfonic acid (5 mol\%)

$\mathrm{CHCl}_{3}, \mathrm{O} \mathrm{C}$
30, $\mathrm{R}=\mathrm{H}$ (PYMP)

31, $\mathrm{R}=\mathrm{NMe}_{2}(\mathrm{DPYMP})$

32, $\mathrm{R}=\mathrm{N}\left(\mathrm{CH}_{2}\right)_{4}($ PPYMP)

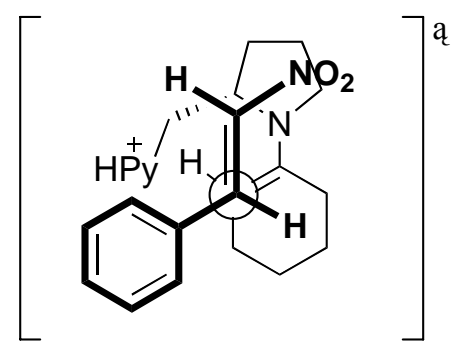

Scheme 22. Asymmetric Michael addition reactions of ketones with nitroolefins catalyzed by pyrrolidine-pyridine conjugate base catalysts 30-32 and the plausible transition state<smiles>C[C@H](N)C(=O)NC(c1ccccc1)c1ccccc1</smiles>

33<smiles>O=C(N[C@H]1c2ccccc2C[C@H]1O)[C@@H]1CCCN1</smiles>

34<smiles>O=C([C@@H]1C[C@@H](O)CN1)N1CCC[C@H]1C(c1ccccc1)c1ccccc1</smiles>

35

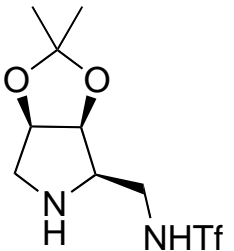

36
37

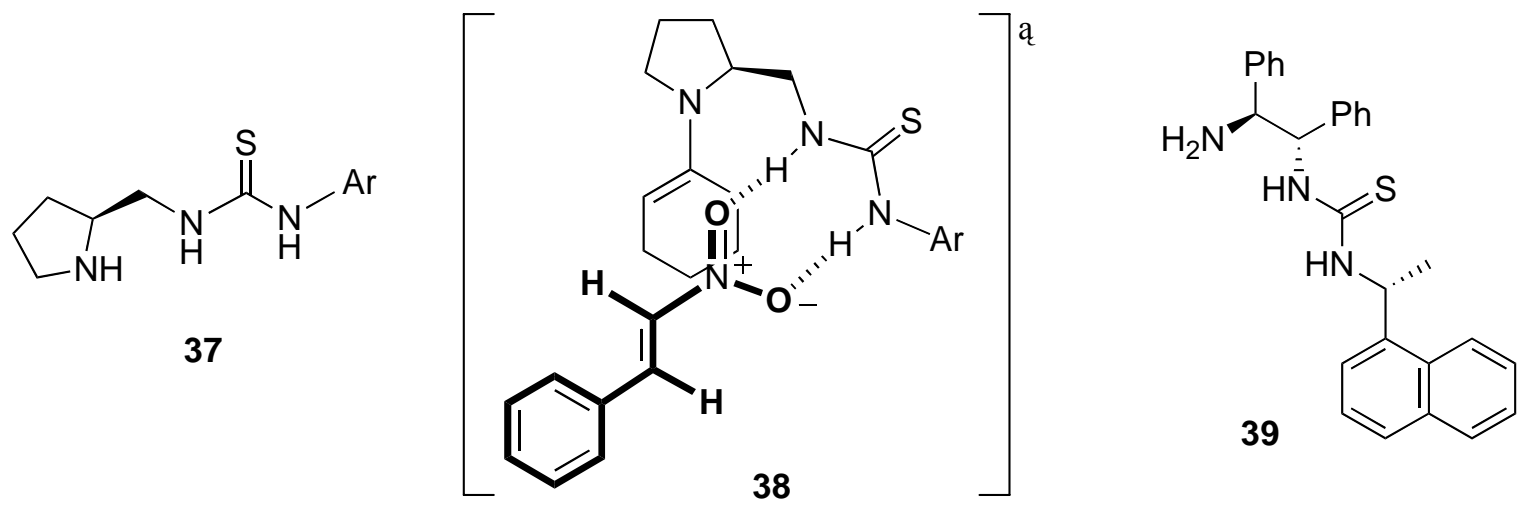

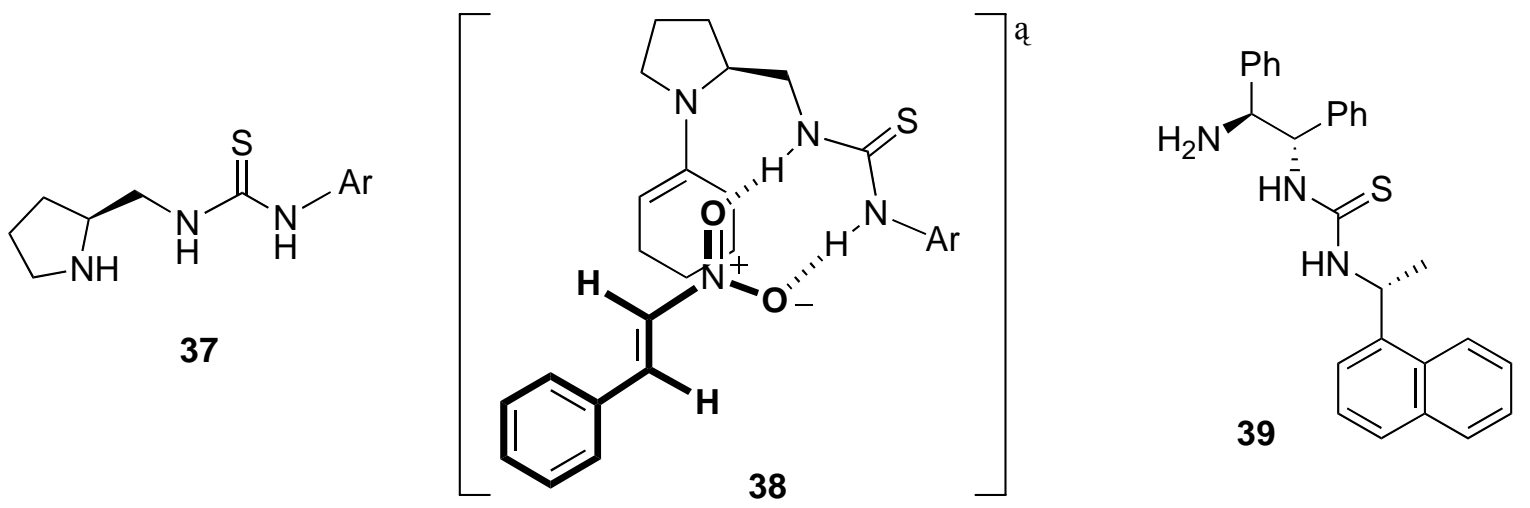
ee up to $99 \%$<smiles>[X]C1=C(Cn2cc[n+](CCCC)c2C)[CH][C@H]1CCCC</smiles>
$\mathrm{X}=\mathrm{Br}$ or $\mathrm{BF}_{4}$

40

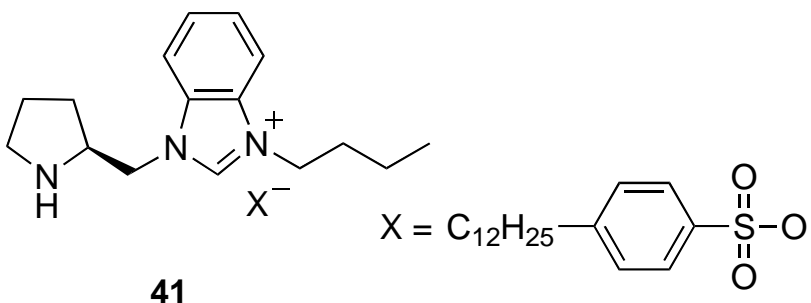

Chart 4. Other types of chiral organocatalysts for asymmetric Michael addition reaction and the proposed transition state 
Finally, we should emphasize that the synergistic effect of both Type I and Type III activation modes provides in some cases a very powerful way to construct relatively complex molecules in a one-pot operation. $^{70,71}$ In particular, such systems are highly successful in intramolecular transformations, as exemplified in Scheme 23. ${ }^{72-74}$<smiles>[X]CCC=CC([R])=O</smiles>

$\mathrm{X}=\mathrm{CH}_{2}$ or NTs

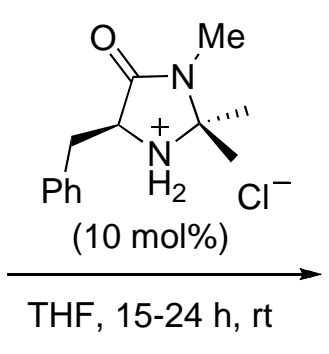<smiles>[R]C(=O)C[C@H]1CC[X]C1C=O</smiles>

yield up to $99 \%$

ee up to $97 \%$

$\mathrm{dr}>49: 1$

Scheme 23. Organocatalytic asymmetric intramolecular Michael addition reactions ${ }^{72 a}$

\section{3. $\alpha$-OXIDATION}

The insertion of an oxygen atom at the $\alpha$-position of carbonyl compounds can be considered to be oxidation in organic synthesis. To induce asymmetry in this process via organocatalysis, nitroso compounds are conveniently used as electrophiles based on a mechanistic resemblance to the aldol reaction, so-called "nitroso aldol reaction". 75

In fact, Zhong, ${ }^{76}$ MacMillan, ${ }^{77}$ Hayashi, ${ }^{78}$ and Córdova ${ }^{79}$ reported independently and almost at the same time that proline could act as an excellent catalyst for aminoxylation reactions with almost perfect enantioselectivities (97-99\% ee) (Scheme 24). This method might be of great value as a metal-free oxidation system.

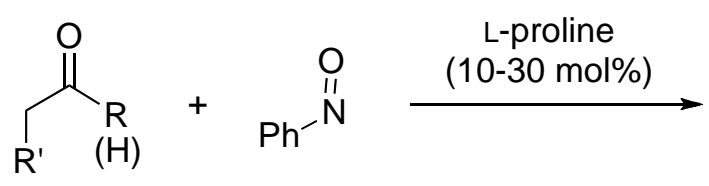

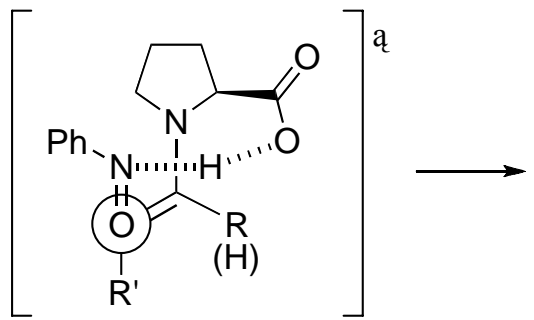

Scheme 24. L-Proline-catalyzed asymmetric $\alpha$-aminoxylation of aldehydes and ketones

Mechanistically, nitroso compounds possess two electrophilic centers, i.e., nitrogen and oxygen atoms, but the exclusive formation of $O$-alkylation products indicates that the hydrogen-bonding transition state seems to be satisfactorily stabilized with the more basic nitrogen atom. ${ }^{79 b}, 80,81$ Interestingly, when $\alpha$-substituted aldehydes were used as the substrate, considerable $N$-alkylation products were produced 
due to steric repulsion between the alkyl substituent on the enamine double bond and the phenyl group of nitrosobenzene. ${ }^{82}$

After these reports, extensive efforts have been directed to develop more powerful chiral organocatalysts as well as to increase the efficiency by conducting the reactions in ionic liquids. ${ }^{83-88}$

Córdova and coworkers actively sought out other possible oxidizing agents, and found that iodosobenzene, $\mathrm{N}$-sulfonyloxaziridines, and even molecular oxygen could affect efficiently an oxygen atom transfer (Scheme 25). ${ }^{89,90}$

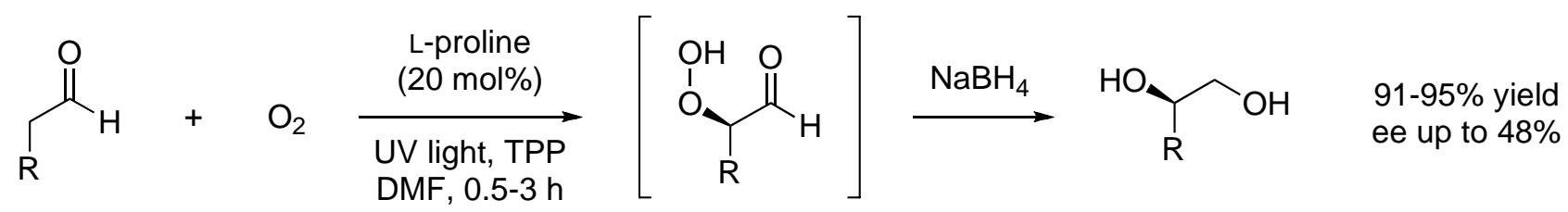

Scheme 25. Direct L-proline-catalyzed asymmetric oxidation of aldehydes with molecular oxygen

The $\alpha$-aminoxylation procedure is also useful for achieving asymmetric desymmetrization of meso-compounds. ${ }^{91}$ Furthermore, the synthetic utility of this method can be increased greatly by combining it with other functional group transformations, e.g., reduction, reductive amination, allylation, and Wittig olefination (Scheme 26). ${ }^{76,77,92-95}$ An example in which it is applied to natural product synthesis has also been reported in the literature. ${ }^{73,96,97}$

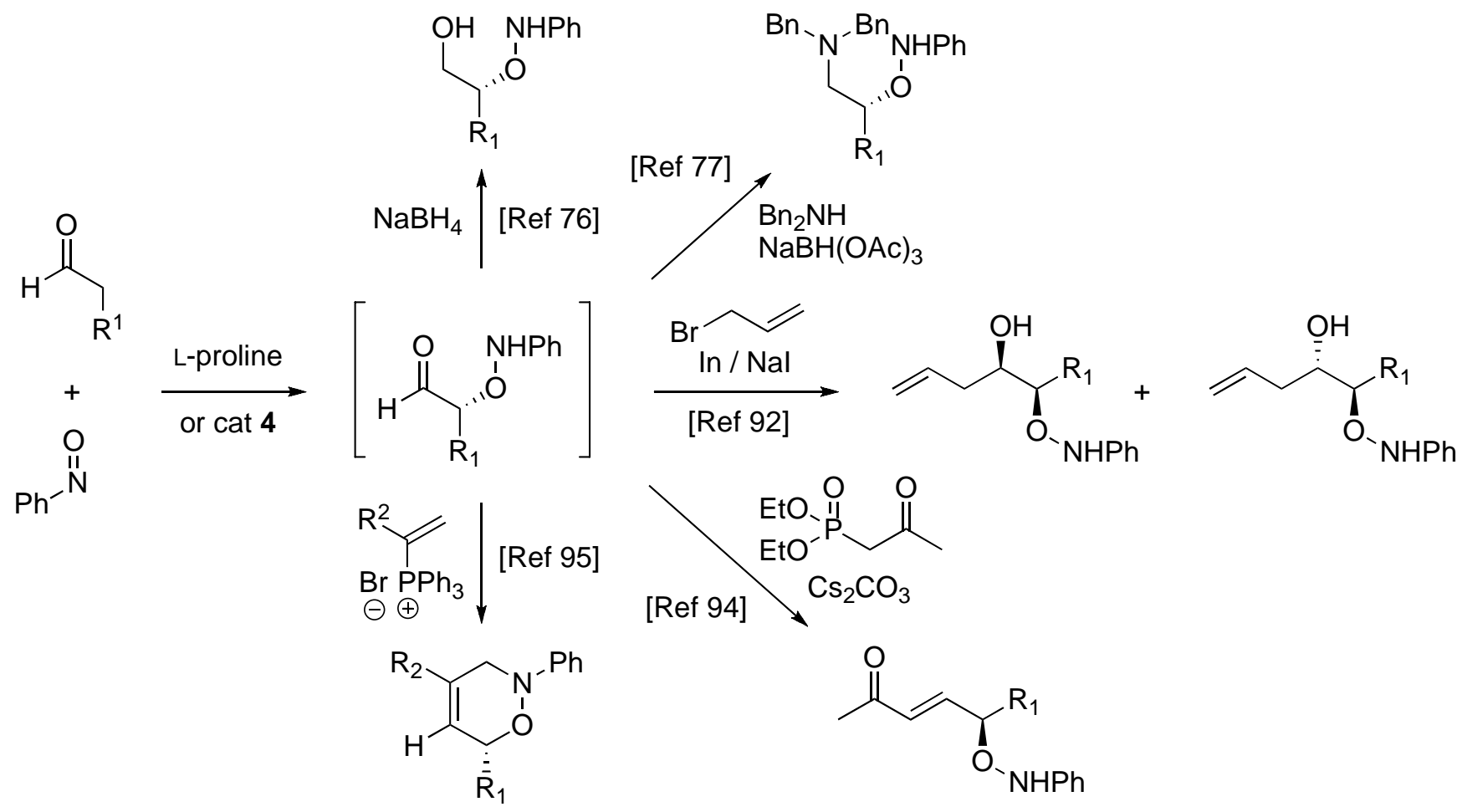

Scheme 26. Synthetic versatility of L-proline-catalyzed asymmetric $\alpha$-aminoxylation 
Finally, Yamamoto and coworkers could succeed in extending the scope of this chemistry to conjugate enone systems, providing nitroso Diels-Alder adducts with excellent enantioselectivities (98-99\% ee) (Scheme 27). ${ }^{98}$<smiles></smiles><smiles>O=Nc1ccccc1</smiles>
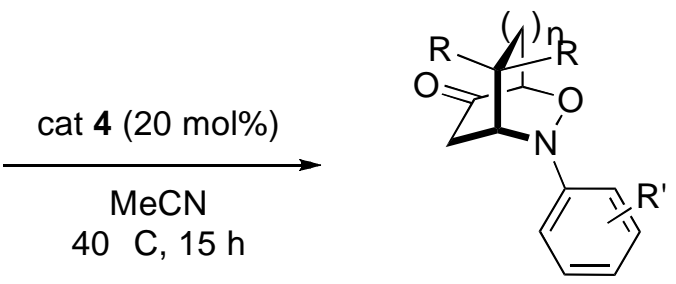

$14-64 \%$ yield $98-99 \%$ ee

Scheme 27. Organocatalytic asymmetric tandem $O$-nitroso aldol / Michael addition reactions

\section{4. $\alpha$-AMINATION}

Asymmetric amination at the $\alpha$-position of a carbonyl compound is an important tool in organic synthesis due to its facile ability to provide biologically interesting $\alpha$-amino acids and $\alpha$-amino alcohols. This can be considered to be an analog of $\alpha$-oxidation using appropriate nitrogen-based electrophiles. ${ }^{75 c-75 e, 99}$ The first efficient approach in this field was accomplished by Jørgensen and List independently almost at the same time using azodicarboxylate derivatives in the presence of L-proline as a catalyst (yield up to $99 \%$, ee up to $97 \%$ ) (Scheme 28$).{ }^{100,101}$
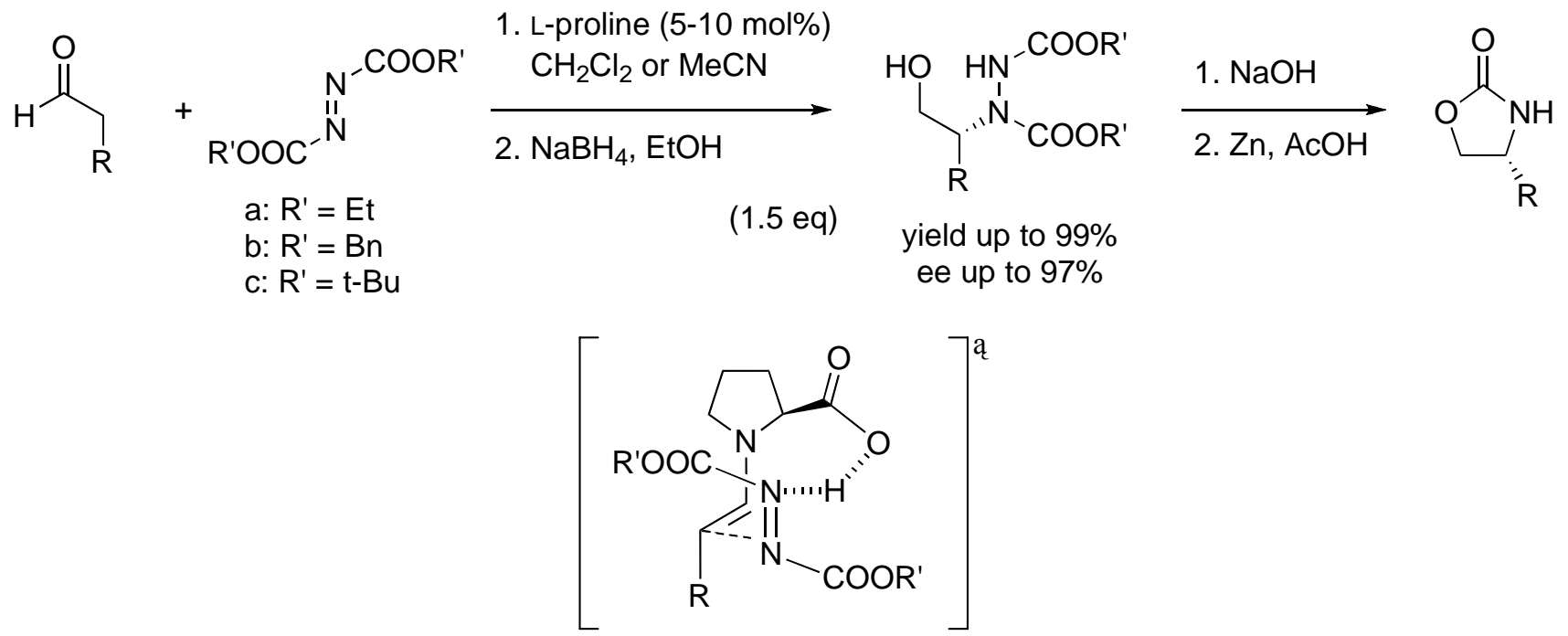

Scheme 28. L-Proline-catalyzed asymmetric $\alpha$-amination of aldehydes and the proposed transition state

Interestingly, when catalyst 8 was used, the corresponding $S$-enantiomer was obtained in good yields and with excellent enantioselectivities (yield up to $88 \%$, ee up to 97\%) (Scheme 29). ${ }^{2 \mathrm{~b}}$ The observed stereochemistry can be explained by considering the steric repulsion between the catalyst side chain and 
the azodicarboxylate ester electrophile. This type of catalyst is also known to be effective for the $\gamma$-amination of $\alpha, \beta$-unsaturated aldehydes in the presence of a catalytic amount of benzoic acid as an additive. ${ }^{102}$

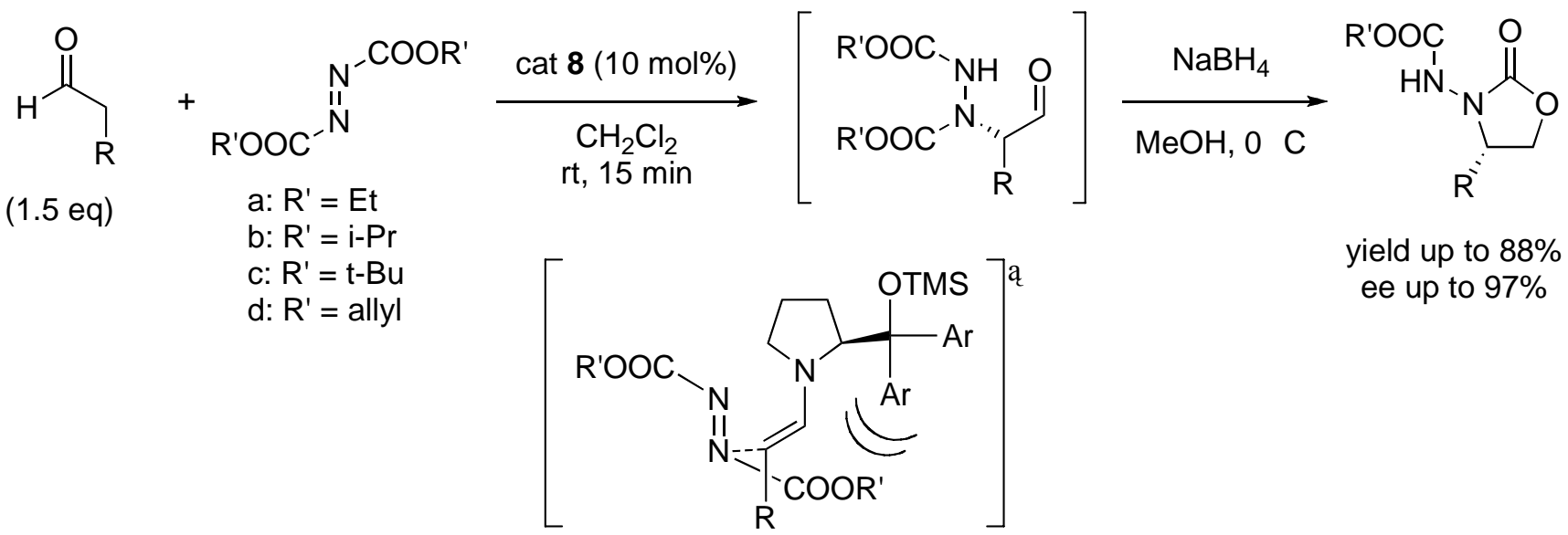

Scheme 29. Organocatalytic asymmetric $\alpha$-amination of aldehydes and the proposed transition state

There have been some reports on the use of other types of catalysts or ionic liquids as novel reaction media. ${ }^{103-106}$ The asymmetric amination of $\alpha$-branched aldehydes provides a particularly efficient way to prepare $\alpha, \alpha$-disubstituted amino aldehydes with excellent enantioselectivities (ee up to 99\%). ${ }^{104,107,108}$ Barbas III and coworkers developed another ingenious strategy using aldehydes, ketones, and azodicarboxylates to prepare $\beta$-amino alcohol derivatives with two stereogenic carbon centers in a one-pot operation (Scheme 30). ${ }^{109}$

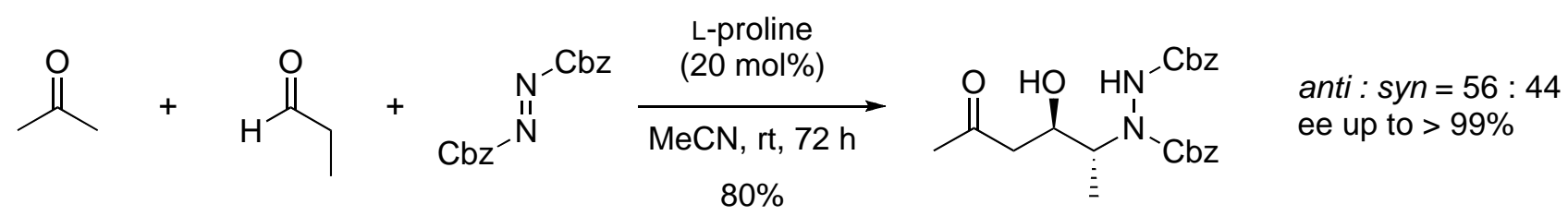

Scheme 30. L-Proline-catalyzed asymmetric synthesis of functionalized $\beta$-amino alcohols

The combination of the asymmetric amination and the Wittig olefination provides an efficient entry to chiral dihydropyridazine derivatives with good yields via a one-pot operation. ${ }^{110}$ In addition to azodicarboxylate, in some cases nitroso compounds can act as amine sources. ${ }^{82,111}$ Finally, there have been some reports on the mechanistic investigation of asymmetric amination. ${ }^{80 \mathrm{~b}, 80 \mathrm{c}, 112}$

\section{5. $\alpha$-SULFENYLATION / SELENENYLATION}

Among several methods for the introduction of a hetero-atom at the $\alpha$-position of aldehydes or ketones by 
organocatalysis, synthetic studies of $\alpha$-sulfenylation and -selenenylation are relatively rare. ${ }^{75 d, 75 e}$ In 2004 , Wang and coworkers reported the first example of the nonasymmetric $\alpha$-sulfenylation of aldehydes and ketones using $N$-(phenylthio)phthalimide as a sulfenylating agent in the presence of $20-30 \mathrm{~mol} \%$ of $\mathbf{9} .{ }^{113}$ Similarly, they also established an $\alpha$-selenenylation method using $N$-(phenylseleno)phthalimide as a selenium source. ${ }^{114}$

Soon after that, Jørgensen and coworkers discovered a highly enantioselective process for the $\alpha$-sulfenylation of aldehydes using catalyst 8 (ee up to 98\%) (Scheme 31 ). ${ }^{21 \mathrm{~b}, 115}$

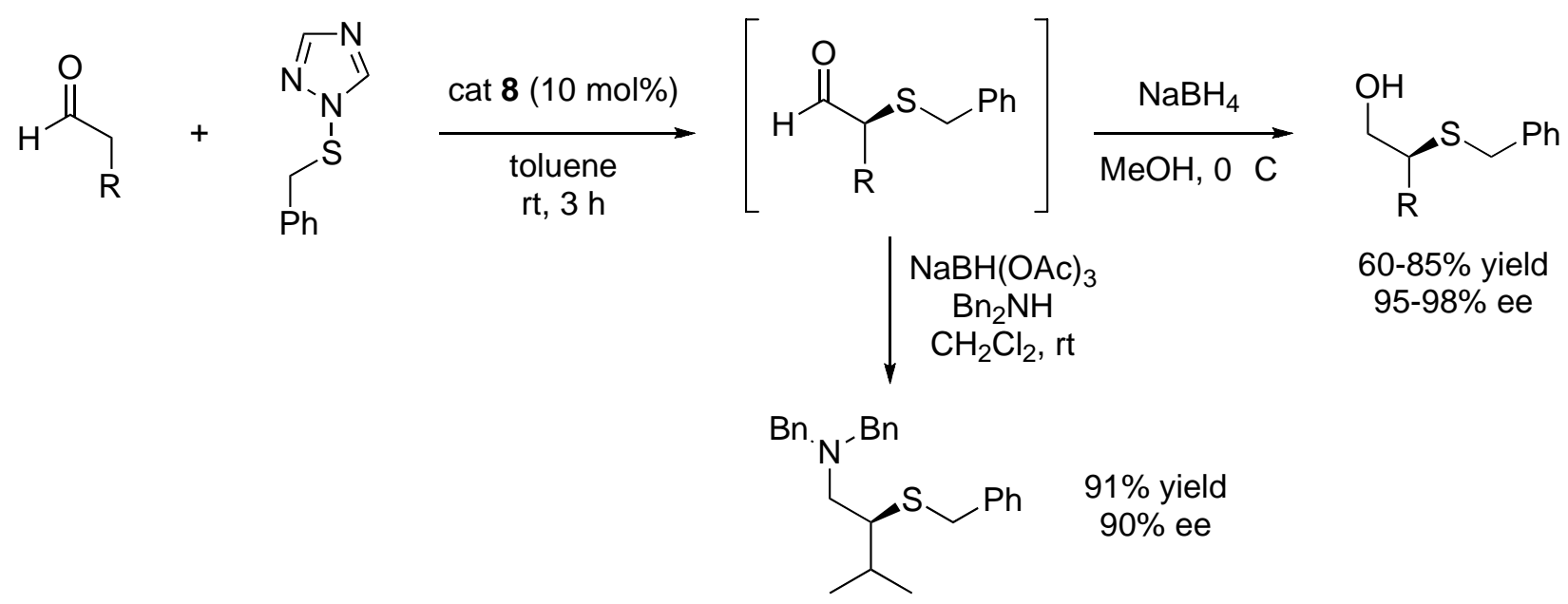

Scheme 31. Organocatalytic asymmetric $\alpha$-sulfenylation of aldehydes

\section{6. $\alpha$-HALOGENATION}

Finally, in the context of $\alpha$-heteroatom functionalization we discuss the asymmetric halogenation of carbonyl compounds. Due to the ease of manipulation and also the biological importance of enantiomerically pure $\alpha$-halogenated carbonyl species, great attention has recently been focused on this challenging subject, in particular, to confirm the feasibility of organocatalytic transformations. ${ }^{75 \mathrm{~d}, 75 \mathrm{e}, 116}$ In 2005, the asymmetric $\alpha$-fluorination of aldehydes was announced in succession from four different research groups: Enders, ${ }^{117}$ Jørgensen, ${ }^{21 b,}{ }^{118}$ Barbas III, ${ }^{119}$ and MacMillan. ${ }^{120}$ In the latter three groups $N$-fluorobenzenesulfonimide (NFSI) was used as the fluorinating agent and excellent enantioselectivities were obtained (86-99\% ee) (Scheme 32).

The asymmetric $\alpha$-chlorination of aldehydes was also developed independently by two groups: MacMillan $^{121}$ and Jørgensen. ${ }^{122}$ Among several chlorinating agents, they found that perchlorinated quinone 44 and $N$-chlorosuccinimide (45) were the best, albeit the catalytic conditions were slightly different (Scheme 33). The synthetic utility of this method was established by further manipulation to various important chiral building blocks such as amino acids, epoxides, chlorohydrins, and amino alcohols. 


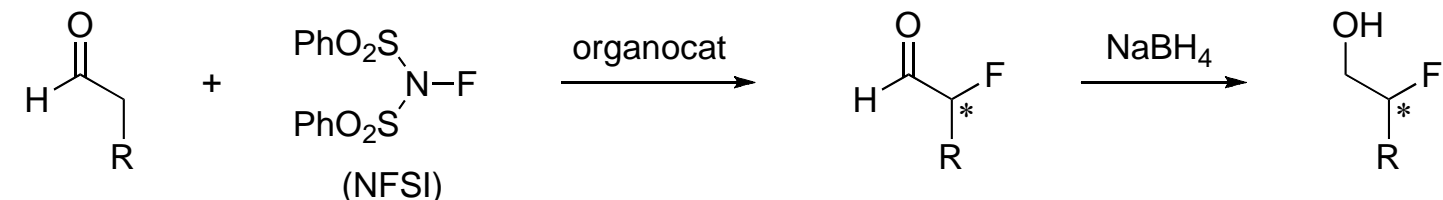

Ref. 118: configuration $=S$ cat 8 (1 mol\%) in t-BuOMe, rt $55-95 \%$ yield 91-97\% ee
Ref. 119: configuration $=S$ cat 42 (100 mol\%) in DMF, 4 C $40-97 \%$ yield $86-96 \%$ ee<smiles>CN1C(=O)[C@@H](Cc2ccccc2)NC1(C)C</smiles>

Ref. 120: configuration $=R$ cat 43 (20 mol\%) in THF / i-PrOH, Š10 C $54-96 \%$ yield 91-99\% ee<smiles>CN1C(=O)[C@@H](Cc2ccccc2)NC1(C)C</smiles>

43

Scheme 32. Organocatalytic asymmetric $\alpha$-fluorination of aldehydes

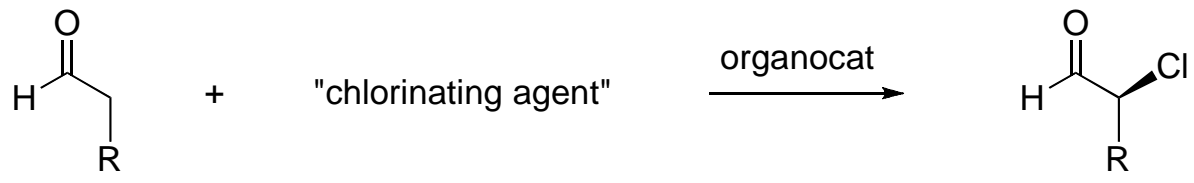<smiles>O=C1C(Cl)=C(Cl)C(Cl)=C(Cl)C1(Cl)Cl</smiles>

Ref. 121: reagent 44 cat $42 \mathrm{CF}_{3} \mathrm{COOH}(5 \mathrm{~mol} \%)$ in acetone, Š30 C $71-94 \%$ yield $80-95 \%$ ee<smiles>O=C1CCC(=O)N1Cl</smiles>

Ref. 122a: reagent 45 cat 25 (10 mol\%) in $\mathrm{CH}_{2} \mathrm{Cl}_{2}$, rt $30-99 \%$ yield $81-97 \%$ ee

Scheme 33. Organocatalytic asymmetric $\alpha$-chlorination of aldehydes

Compared to the preceding examples, the $\alpha$-chlorination of ketones was rather difficult. This problem was cleanly solved by Jørgensen and coworkers simply by switching the $C_{2}$-symmetry character of the organocatalyst from 25 to $\mathbf{4 6}$, which provided various $\alpha$-chloroketones with moderate to high yields and excellent enantioselectivities (Scheme 34). ${ }^{123}$ This was also proven to be an excellent strategy in the asymmetric $\alpha$-bromination of aldehydes and ketones. ${ }^{124}$<smiles>O=C1CCCCC1</smiles>

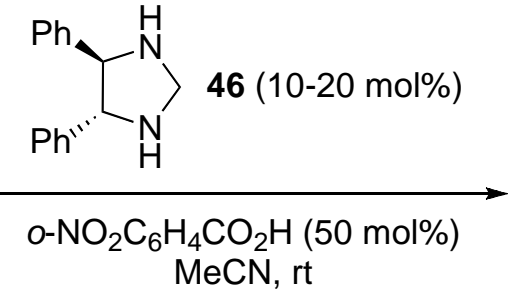<smiles>O=C1CCCCC1Cl</smiles>

Scheme 34. Organocatalytic asymmetric $\alpha$-chlorination of ketones 


\section{CYCLOADDITION REACTIONS}

The Diels-Alder reaction is one of the most powerful tools in organic synthesis, and over the past 30 years considerable attention has been focused on the development of efficient asymmetric transformations. While the discovery of new asymmetric catalysts is an important event in this field, we can also take advantage of organocatalytic systems. ${ }^{125}$

In 2000, MacMillan and coworkers were the first to demonstrate a new elegant non-metallic method for the asymmetric Diels-Alder reaction of cyclopentadiene with $\alpha, \beta$-unsaturated aldehydes in the presence of the imidazolidinone-type catalyst 42 (Scheme 35). ${ }^{126}$ The reaction proceeded well to afford the enantiomerically enriched cycloadducts in high yields (75-99\%) and with excellent enantioselectivities (endo-isomer, up to $93 \%$ ee; exo-isomer, up to $93 \%$ ee). Soon after that, they confirmed that this organocatalytic strategy could be extended to $\alpha, \beta$-unsaturated ketones as dienophiles. ${ }^{127}$

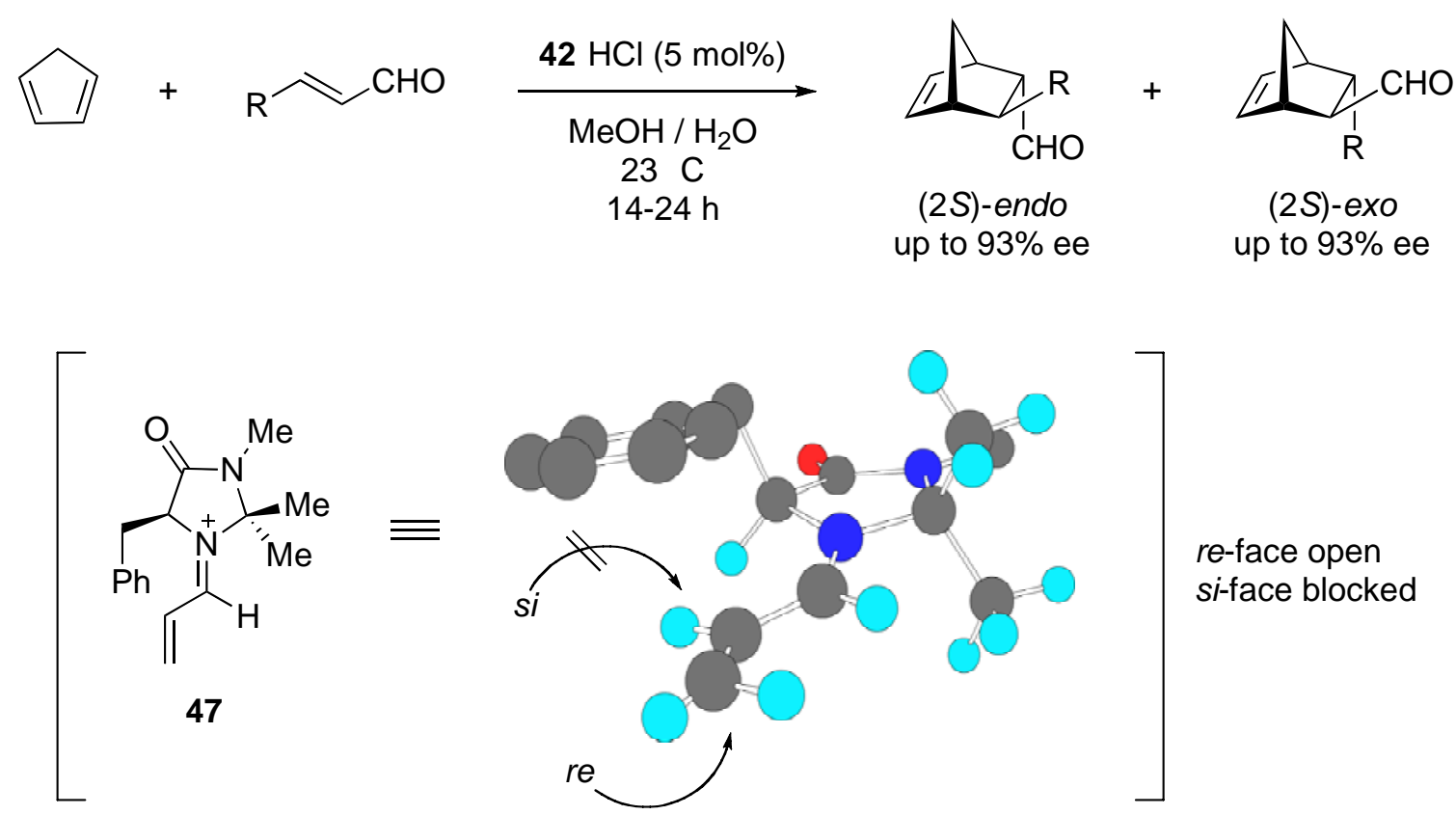

Scheme 35. Organocatalytic asymmetric Diels-Alder reaction of cyclopentadiene with $\alpha, \beta$-unsaturated aldehydes

Compared to the existing techniques using traditional chiral Lewis acid catalytic systems, the organocatalytic approach is completely different with respect to the activation mode. Thus, reversible formation of the LUMO-lowering iminium ion complex 47 from $\alpha, \beta$-unsaturated aldehydes and chiral catalyst 42 can determine the efficiency of this asymmetric process. ${ }^{128}$ There are two important factors in this proposed intermediate: selective formation of the $(E)$-iminium conformer and effective shielding of the si-face of the iminium ion dienophile through the benzyl side chain on the imidazolidinone catalyst framework, as depicted in Scheme 35. 
The major limitations in this chemistry are the relatively long reaction time and the high catalyst loading. In order to solve these problems, there have been some reports on the activation of these reactions under microwave irradiation ${ }^{56 \mathrm{~g}}$ and recycling of the catalysts by attaching a fluorous tag. ${ }^{129}$

The feasibility of the present organocatalytic activation mode was further demonstrated by applying it to natural product synthesis. ${ }^{130,131}$ MacMillan and coworkers have recently succeeded in extending the scope of this methodology to enantioselective intramolecular Diels-Alder reactions. ${ }^{132,133}$ The utility of this method was typically exemplified by the short and efficient synthesis of the marine metabolite solanapyrone D in an enantiomerically pure form (Scheme 36$)$.
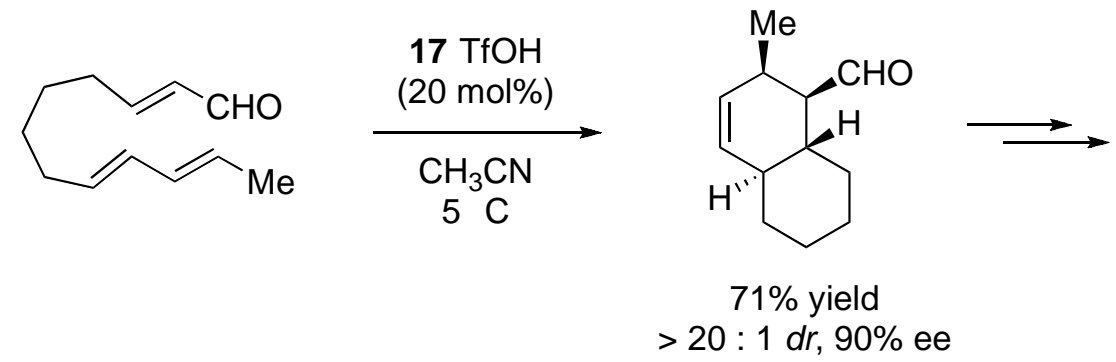

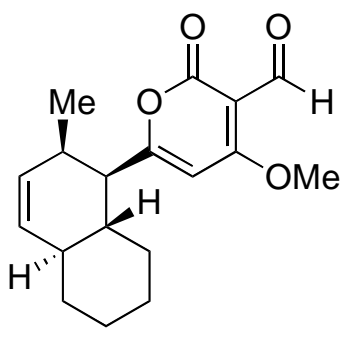

Solanapyrone D

Scheme 36. Organocatalytic asymmetric intramolecular Diels-Alder reaction: application to the asymmetric synthesis of solanapyrone $\mathrm{D}^{132}$

In analogy to the organocatalytic LUMO-lowering mode for dienophile activation, the HOMO-elevating strategy for the diene partner via the in situ formation of enaminodiene species from $\alpha, \beta$-unsaturated ketones can act as an alternative pathway to promote asymmetric Diels-Alder reactions (Scheme 37).
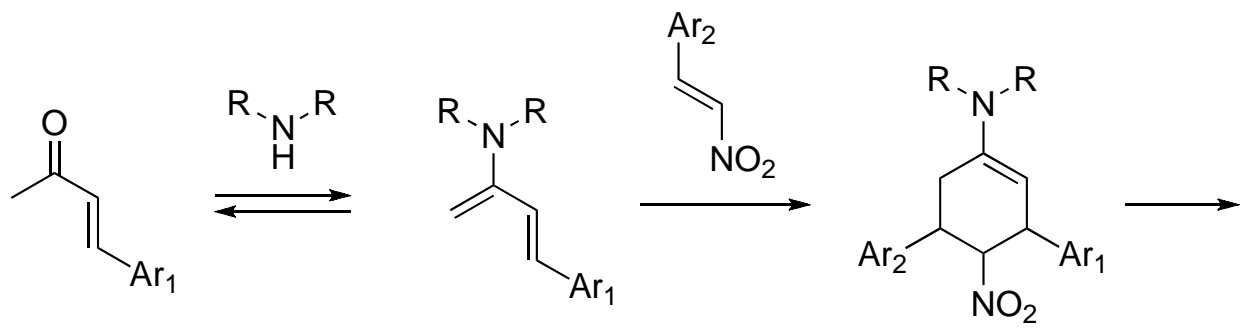<smiles></smiles>

Scheme 37. Organocatalytic Diels-Alder reactions of $\alpha, \beta$-unsaturated ketones with nitroolefins

Consistent with this expectation, Barbas III and coworkers reported an efficient entry to the concise synthesis of highly substituted cyclohexanone derivatives in a one-pot operation, albeit with moderate enantioselectivities (up to $38 \%$ ee). ${ }^{134}$ Although we can not preclude the possibility that the reaction pathway might be a double Michael addition reaction, this method is noteworthy in terms of its simplicity and novelty. In connection with this chemistry, new findings regarding an organocatalytic asymmetric 
hetero-domino Knoevenagel-Diels-Alder-Epimerization strategy have also been reported. ${ }^{135}$

The organocatalytic asymmetric transformations were also applied to the inverse-electron-demand hetero-Diels-Alder reaction. Thus, after screening a series of pyrrolidine catalysts, Jørgensen and coworkers found that catalyst $\mathbf{2 4}$ was particularly useful for this purpose: after PCC oxidation, lactone products were formed as a single diastereomer in excellent enantioselectivity (80-94\% ee) (Scheme 38). ${ }^{136}$ The proposed transition state indicates effective shielding of the si-face of the enamine double bond by the diarylmethyl substituent on the pyrrolidine ring of the catalyst.<smiles>[R]C=CC(=O)C([R])[O-]</smiles>

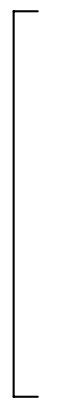

\section{1. cat 24 (10 mol\%)}

silica, $\mathrm{CH}_{2} \mathrm{Cl}_{2}$, Š $15 \mathrm{C} \rightarrow \mathrm{rt}$

2. $\mathrm{PCC}, \mathrm{CH}_{2} \mathrm{Cl}_{2}$<smiles>[R]OC(=O)C1=CC([R])C([R])C(=O)O1</smiles>

$62-93 \%$ yield $80-94 \%$ ee

Scheme 38. Organocatalytic asymmetric inverse-electron-demand Diels-Alder reactions and the proposed transition state ${ }^{136 a}$

MacMillan's catalytic system was also effective for enantioselective 1,3-dipolar cycloaddition using nitrone substrates, in providing the isoxazolidine derivatives in good yields and in high diastereo- and enantioselectivities (Scheme 39). ${ }^{137,138}$

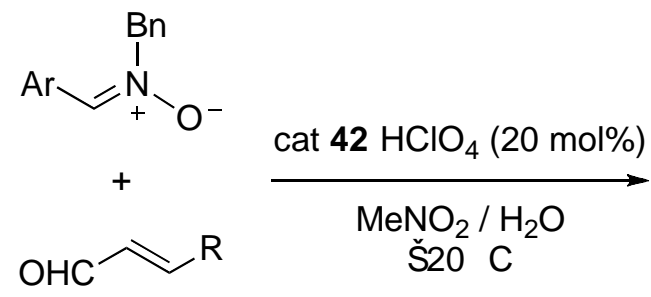

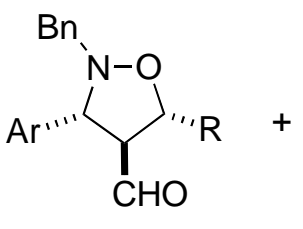

endo<smiles>[R]C1ON(Cc2ccccc2)C([AlH2])C1C</smiles>

exo yield up to $98 \%$ endo : exo up to $99: 1$ ee (endo) up to $99 \%$

Scheme 39. Organocatalytic asymmetric 1,3-dipolar cycloaddition reactions

The versatile nature of asymmetric organocatalysis is also recognized by its application to inter- or intramolecular [4+3]- and [3+3]-cycloaddition reactions (Scheme 40). ${ }^{139,140}$ 


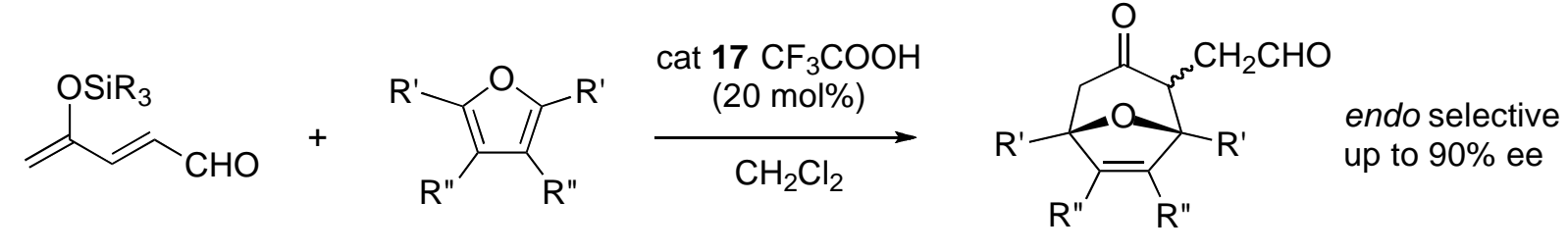

Scheme 40. Organocatalytic asymmetric [4 +3$]$-cycloaddition reaction of furans ${ }^{139}$

\section{MISCELLANEOUS REACTIONS}

\section{8-1. C-C BOND FORMATION}

The initial stage in organocatalysis is mostly driven by the condensation of carbonyl compounds with chiral (secondary) amines to reversibly form iminium ion intermediates. This process is particularly advantageous in lowering the LUMO energy of $\alpha, \beta$-unsaturated carbonyl systems, as described in the preceding section. ${ }^{125,141}$ This evidence suggests that the activation mode of this type may also be applicable to enantioselective electrophilic aromatic substitution, namely, Friedel-Crafts-type alkylation with electron-rich aromatic systems.

In accordance with this expectation, in 2001, MacMillan and coworkers reported the first example of the asymmetric Friedel-Crafts alkylation of $N$-methylpyrrole using imidazolidinone catalyst 42 as its trifluoroacetate salt (Scheme 41). ${ }^{142 a}$ This method is effective for a variety of $\alpha, \beta$-unsaturated aldehydes as acceptors and alkylation products were obtained in good yields and with moderate to excellent enantioselectivities (87-97\% ee). Furthermore, the utility of this method is established in the alkylation of other electron-rich aromatic compounds (Scheme 42). ${ }^{142 b, 142 \mathrm{c}}$ The observed stereochemistry of the products can be explained again by invoking the iminium ion transition state 47 similarly as shown in Scheme 35, leaving the re face open to aromatic nucleophiles. ${ }^{143}$

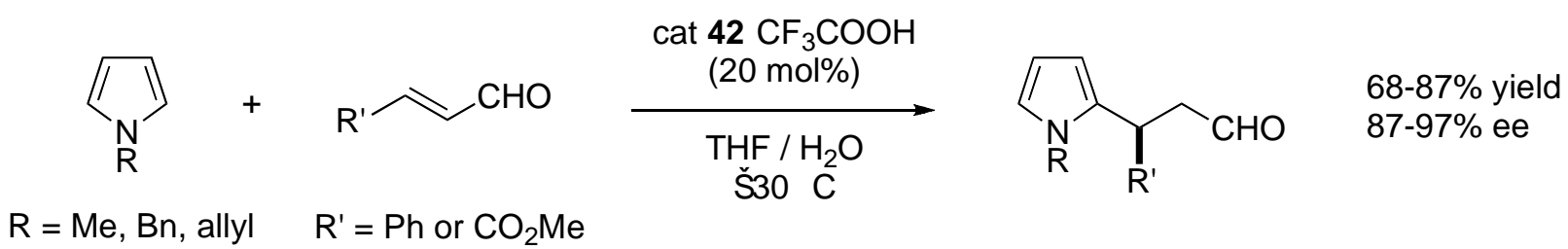

Scheme 41. Organocatalytic asymmetric Friedel-Crafts alkylation of pyrroles
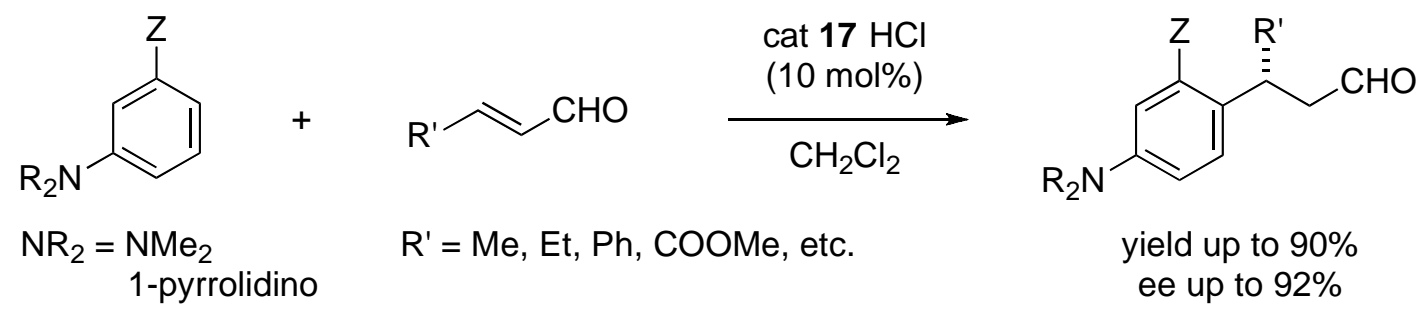

Scheme 42. Organocatalytic asymmetric Friedel-Crafts alkylation of electron-rich benzenes 
To extend the scope of above strategy, several studies on the development of new catalytic systems have been reported in the literature. ${ }^{144-146}$ Unfortunately, however, further extension of this approach to aldehydes or imines as electrophiles was found to be quite difficult without the use of metal catalysts. ${ }^{147}$ One of the interesting features in this chemistry is the discovery by MacMillan and coworkers. ${ }^{148}$ They found that the cascade addition-cyclization reaction of tryptamine derivatives with the activated iminium ion intermediates, arising from catalyst $\mathbf{1 7}$ or $\mathbf{4 8}$ as its trifluoroacetate salt and $\alpha, \beta$-unsaturated aldehydes, constituted an efficient method to prepare the pyrroloindoline ring systems in high enantiocontrol (up to $99 \%$ ee) (Scheme 43).

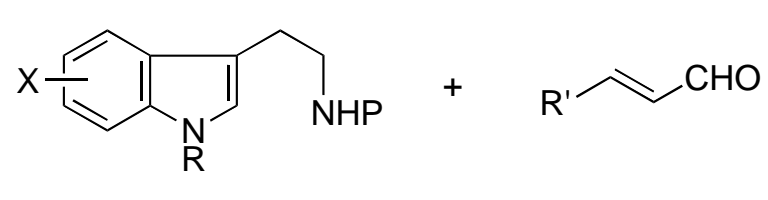

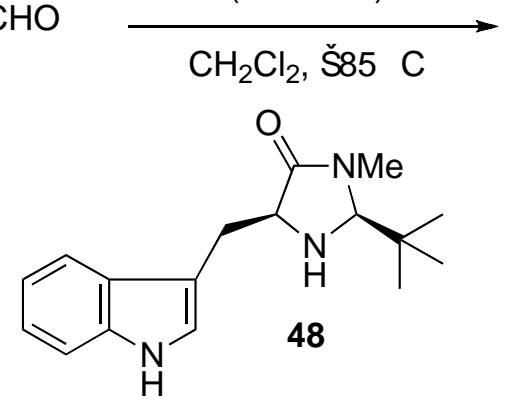

cat 17 or $48 \mathrm{CF}_{3} \mathrm{COOH}$ (20 mol\%)

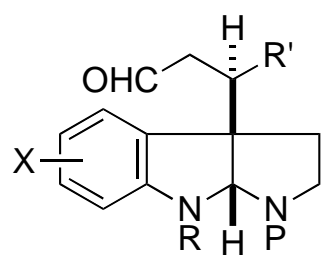

yield up to $97 \%$ dr up to $50: 1$ up to $99 \%$ ee

Scheme 43. Organocatalytic asymmetric synthesis of pyrroloindoline ring systems

Asymmetric organocatalysis also works well with the Morita-Baylis-Hillman reaction. This reaction has been well investigated to provide a multi-component condensation process, and several important contributions have been achieved. However, the use of only L-proline as an organocatalyst is not enough to derive sufficient enantioselectivities, and in many cases the use of a co-catalyst such as imidazole as weak Lewis-base is essential. ${ }^{149-151}$ For example, Miller and coworkers reported that the addition of $N$-methylhistidine-anchored peptides could increase the enantioselectivity of the Morita-Baylis-Hillman process up to $81 \%$ ee (Scheme 44). ${ }^{150 a}$ Examination of the proposed transition state reveals that the chain length of the peptide co-catalyst significantly affects the asymmetric outcome: the optimal result was obtained with an octamer peptide.

On the other hand, Hayashi and coworkers found that tertiary diamine $\mathbf{4 9}$ could efficiently catalyze the desired asymmetric Morita-Baylis-Hillman reaction (ee up to 75\%) (Scheme 45). ${ }^{152}$

Interestingly, in the case of intramolecular L-proline catalysis, an opposite enantioselection was observed depending on the reaction conditions using an imidazole co-catalyst or not (Scheme 46$).{ }^{153}$ In the presence of imidazole, enamine-aldol cyclization presumably takes place through imidazole-iminium ion adduct $\mathbf{B}$ to afford the $(R)$-enantiomer in $80 \%$ ee, whereas the corresponding $(S)$-isomer might be formed under the catalysis of L-proline itself via Zimmerman-Traxler transition state A. 
$\underset{\mathrm{Ar}}{\stackrel{\text { L-proline, co-catalyst }}{(10 \mathrm{~mol} \% \text { each })}} \underset{\mathrm{THF} / \mathrm{CHCl}_{3}, \mathrm{rt}}{\mathrm{O}}$<smiles>[R]NC1CC2CCCC(C1)C2C(=O)[C@H](Cc1cncn1C)NC(=O)OCc1ccccc1</smiles>

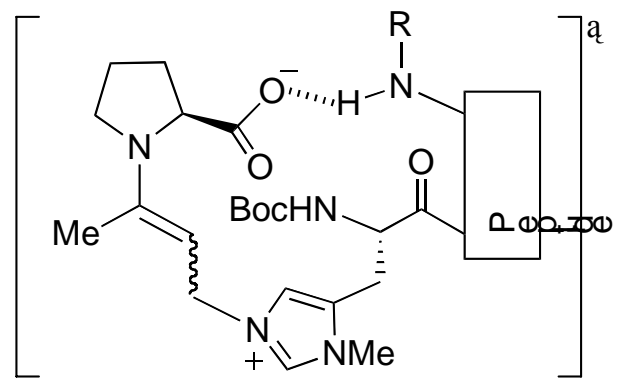

Scheme 44. Organocatalytic asymmetric Morita-Baylis-Hillman reactions and the proposed transition state
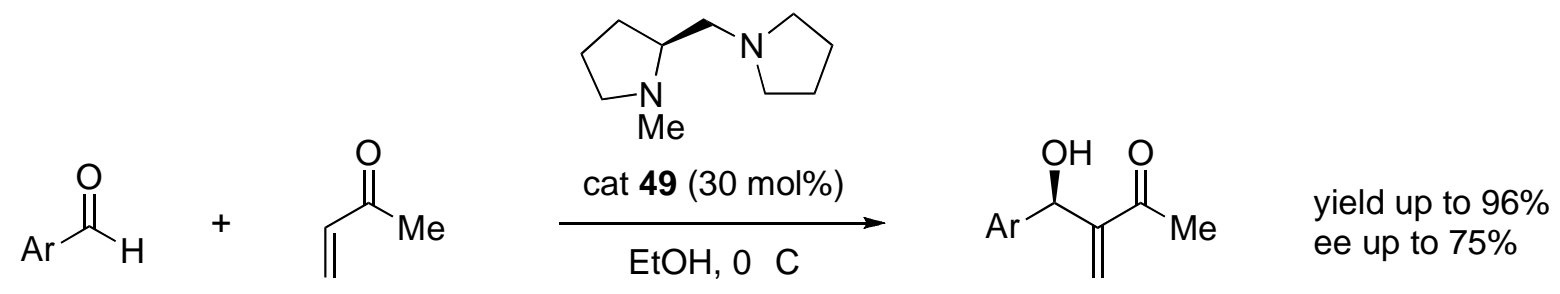

Scheme 45. Diamine-catalyzed asymmetric Morita-Baylis-Hillman reactions<smiles>O=CC1=CCCC[C@H]1O</smiles>

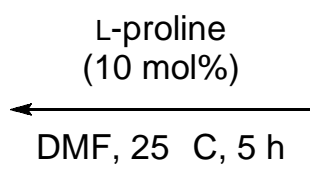

$73 \%$ yield, $45 \%$ ee<smiles>O=C/C=C\CCCC=O</smiles>

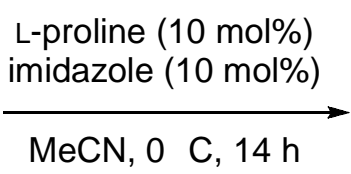<smiles>O=CC1=CCCCC1O</smiles>

$73 \%$ yield, $80 \%$ ee

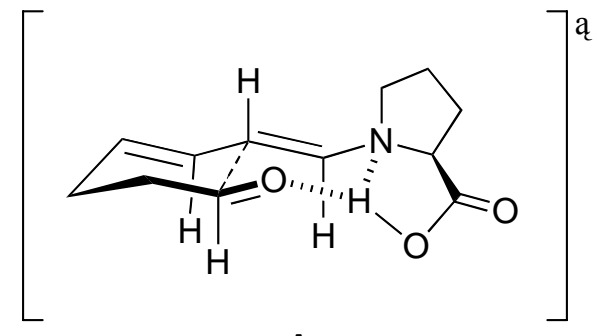

A

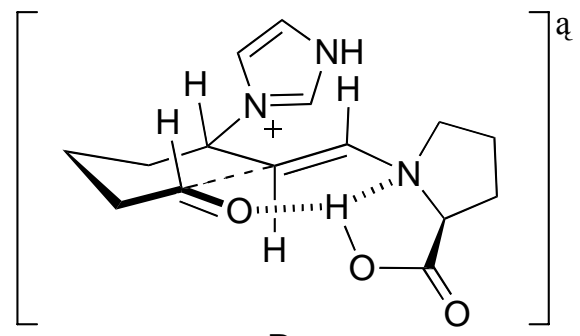

B

Scheme 46. L-Proline-catalyzed asymmetric intramolecular Morita-Baylis-Hillman reactions and the proposed transition states

Organocatalytic alkylation of active methylene compounds with alkyl halides seems to be quite difficult, since $\mathrm{N}$-alkylation of the amine catalyst itself must be always competitive and faster than the required $C$-alkylation process. In contrast to this expectation, List and coworkers provided an elegant method for 
realizing this type of alkylation in high enantioselectivity (Scheme 47). ${ }^{154}$ Apparently, the success of this strategy relies on the careful alignment of the synthetic procedure as follows: 1. the choice of intramolecular alkylation, 2. the use of a stoichiometric amount of triethylamine as a scavenger of HX, and 3. the use of sterically hindered $\alpha$-methylproline as a catalyst. Despite the importance of metal-free alkylation, however, at present there are no other related works in this field. ${ }^{155}$

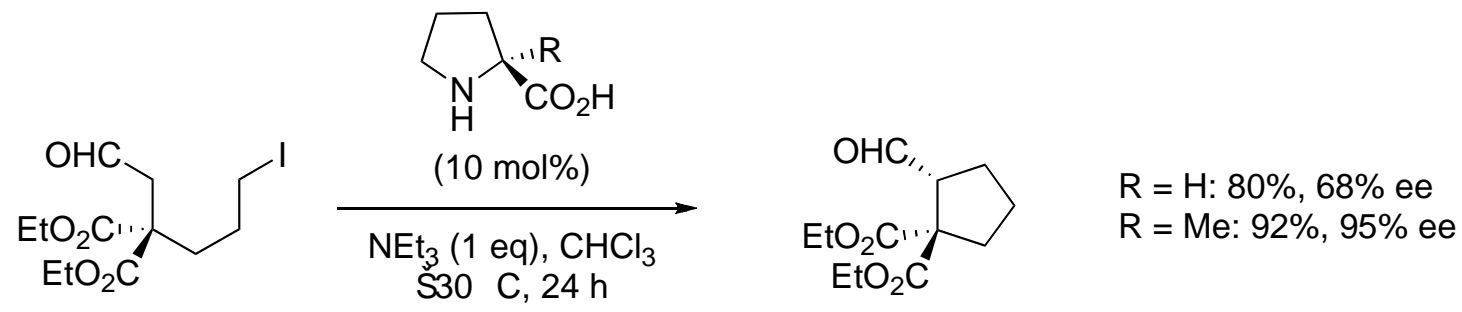

Scheme 47. Organocatalytic asymmetric intramolecular alkylation of aldehydes

While some examples of proline-catalyzed multi-component condensations have been reported, their enantioselectivities were unknown. ${ }^{156-158}$ A few organocatalytic asymmetric cyclopropanations of $\alpha, \beta$-unsaturated carbonyl compounds have been reported (Scheme 48). ${ }^{159,160}$<smiles>[R]C=CC=O</smiles><smiles>O=C(O)C1Cc2ccccc2N1</smiles><smiles>[R]C1[C@@H]([R])[C@@H]1C=O</smiles>

yield up to $85 \%$ dr up to $72: 1$ ee up to $96 \%$

Scheme 48. Organocatalytic asymmetric cyclopropanation of $\alpha, \beta$-unsaturated aldehydes ${ }^{159}$

Finally, the asymmetric allylation of aldehydes using allyltrichlorosilane catalyzed by a chiral proline $N$-oxide (Scheme 49), ${ }^{161}$ and the amino acid-catalyzed asymmetric cyanosilylation of ketones (Scheme $50)^{162}$ have also been reported. Additionally, the catalytic acylcyanation of imines and [2,3]-Wittig rearrangement of alkenyl ethers has been reported, but no asymmetric induction was confirmed. ${ }^{163,164}$

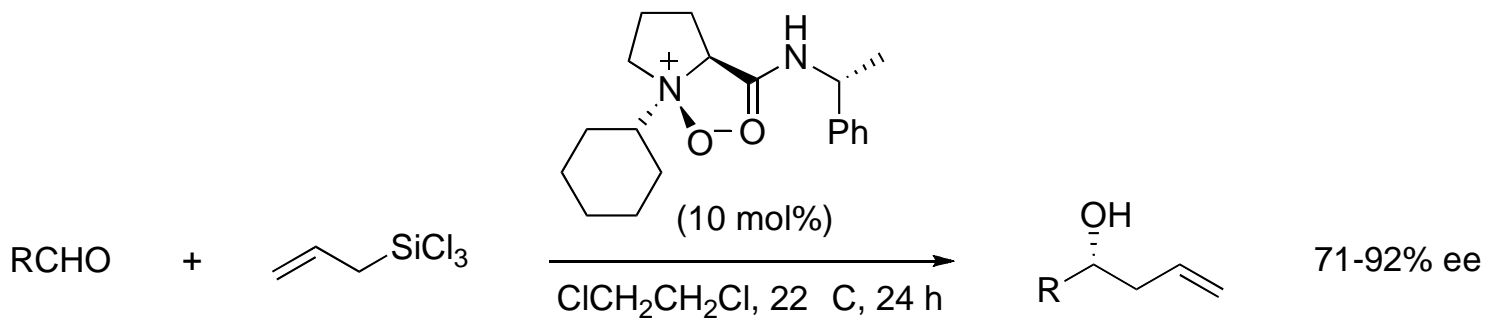

Scheme 49. Organocatalytic asymmetric allylation of aldehydes 


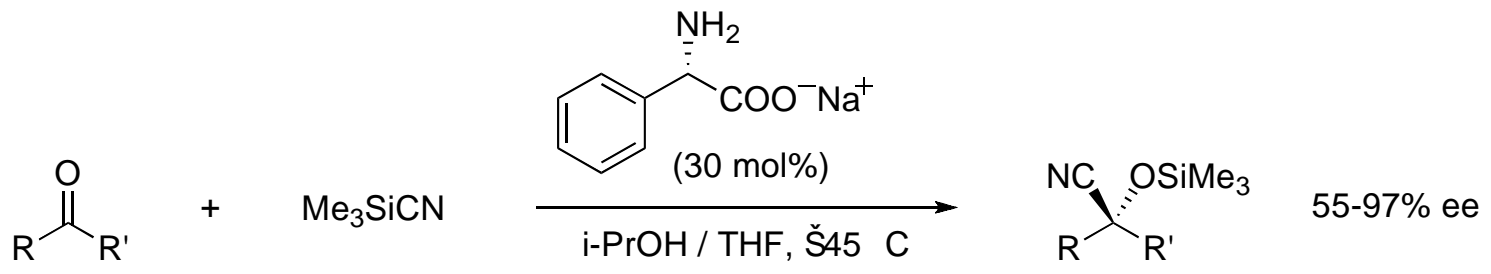

Scheme 50. Organocatalytic asymmetric cyanosilylation of ketones

\section{8-2. EPOXIDATION AND OXIDATION}

As represented by a well-known procedure for Sharpless asymmetric epoxidation, considerable efforts have been made to discover new efficient systems for the asymmetric epoxidation. Compared to the metal-catalyzed systems, the use of organocatalysis seems not to be a favorable strategy, since in many cases oxidation on the catalyst nitrogen atom is unavoidable.

In 2003, soon after their initial finding, ${ }^{165 a}$ Aggarwal and coworkers reported that the asymmetric epoxidation of olefins proceeded in good yields (up to 93\%) and with moderate enantioselectivities (up to $66 \%$ ee) using oxone as an oxidant and a chiral pyrrolidine salt as a catalyst (Scheme 51). ${ }^{165 b, 165 \mathrm{c}}$ According to their proposal, the protonated ammonium salt species can act not only as a phase transfer catalyst to carry the real oxidant species to the organic phase, but also as a promoter to activate the chiral oxidant via hydrogen bonding stabilization, as depicted in Scheme 51.

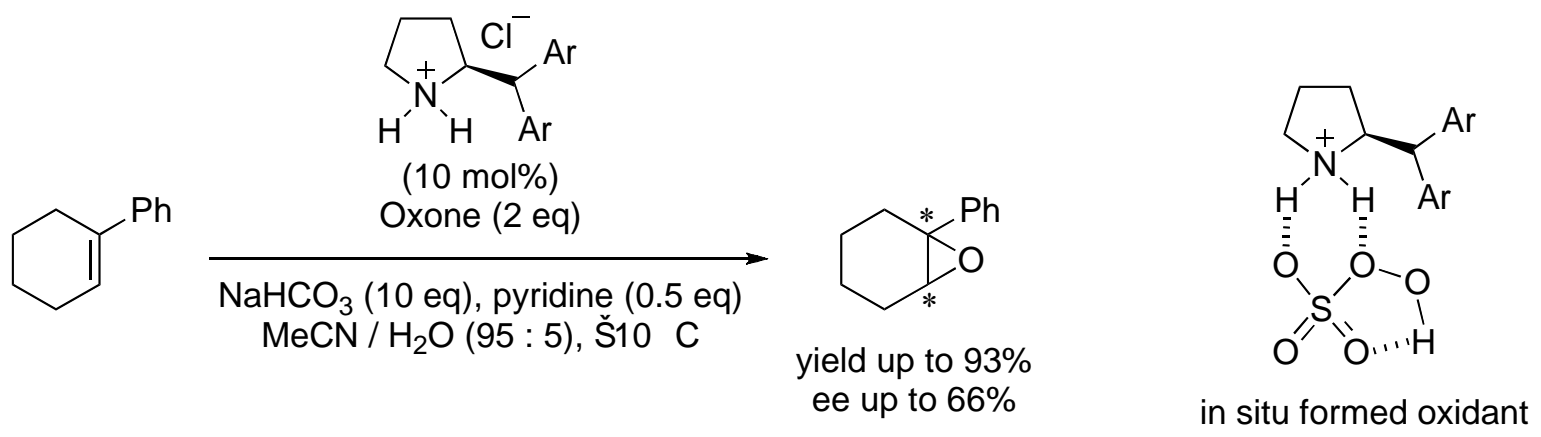

Scheme 51. Asymmetric epxidation of olefins ctalyzed by chiral amines and the proposed in situ formed oxidant $\mathrm{t}^{165 \mathrm{~b}}$

There have since been several reports of the asymmetric epoxidation of $\alpha, \beta$-unsaturated carbonyl compounds using in many cases chiral diaryl prolinol catalysts, and these are listed in Scheme 52. ${ }^{166-169}$ Recently, MacMillan and coworkers reported a new asymmetric epoxidation system composed of hypervalent iodine reagent as an oxidant in the presence of chiral imidazolidinone catalysts designed by themselves. ${ }^{170}$ Although these efforts are truly very valuable in demonstrating the versatility of asymmetric organocatalysis, this area seems to be still at the introductory stage, and further improvements are necessary. ${ }^{171}$ 
$\mathrm{R}$<smiles>[R]C(=O)/C=C(\[R])C</smiles>

Ref. 166a: R" = H

oxidant $=\mathrm{H}_{2} \mathrm{O}_{2}$

cat $8(10 \mathrm{~mol} \%)$ in $\mathrm{EtOH} / \mathrm{H}_{2} \mathrm{O}$, rt

yield up to $56 \%$

dr up to 86 : 14 , ee up to $96 \%$<smiles>COc1c(C)cc(C(O)(c2cc(C)c(OC)c(C)c2)C2CCCN2)cc1C</smiles>

Ref. 168: R" = Ar or R

oxidant $=\mathrm{t}-\mathrm{BuOOH}$

cat 50 (30 mol\%) in hexane, rt

yield up to $98 \%$

ee up to $90 \%$ organocat<smiles>[R]C(=O)[C@H]1OC1([R])[R]</smiles>

Ref. 167a: $\mathrm{R}^{\prime \prime}=\mathrm{H}$

oxidant $=\mathrm{H}_{2} \mathrm{O}_{2}$

cat 18 (30 mol\%) or $13(10 \mathrm{~mol} \%)$ in $\mathrm{CHCl}_{3}$, rt yield up to $99 \%$

dr up to $96: 4$, ee up to $98 \%$<smiles>Cc1cc(C)cc(C(O)(c2cc(C)cc(C)c2)[C@@H]2C[C@H](Br)CN2)c1</smiles>

Ref. 169b: R" = Ar or R

oxidant $=\mathrm{t}-\mathrm{BuOOH}$

cat 51 (30 mol\%) in hexane, rt

yield up to $90 \%$

ee up to $96 \%$

Scheme 52. Organocatalytic asymmetric epoxidation of $\alpha, \beta$-unsaturated carbonyl compounds

Finally, with regard to asymmetric allylic oxidation using proline as a catalyst, only references are shown for convenience. ${ }^{172}$

\section{8-3. REDUCTION}

In connection with the general interest in imitating biological reduction systems using a coenzyme such as $\mathrm{NADH}$ and $\mathrm{FADH}_{2}$ in organic synthesis, organocatalyst-based hydride reduction has gained considerable attention from synthetic chemists.

List $^{173}$ and MacMillan ${ }^{174}$ reported independently that the conjugate reduction of $\alpha, \beta$-unsaturated aldehydes or ketones could efficiently proceed by the reaction with a stoichiometric amount of Hantzch ester 52 under the catalysis of imidazolidinone 53 in excellent enantioselectivities (90-97\% ee) (Scheme 53). ${ }^{174 a}$ Interestingly, even if the reaction was started from an isomerically pure $E$ - or Z-olefin substrate, the product with a same $(S)$-configuration was obtained at a high level of enantioselectivity. The result indicates that in either case the initially formed iminium salt should isomerize quickly into the thermodynamically more stable isomer via dienamine intermediate $\mathbf{5 4}$, followed by asymmetric transfer hydrogenation.

The utility of this hydrogenation procedure was further expanded by combination with Knoevenagel condensation, which provides a powerful new protocol for the multi-component alkylation strategy in a one-pot operation. ${ }^{175}$ There are some reports on the use of organocatalysts like 55-57 as a Lewis base and trichlorosilane as a reducing agent for the enantioselective reduction of imines (Scheme 54). ${ }^{176-178}$ In 
catalyst design, there are important factors: favorable arrangement of the dual coordination site within the catalyst framework toward the Lewis acidic silicon atom and close interaction between the catalyst and the substrate.
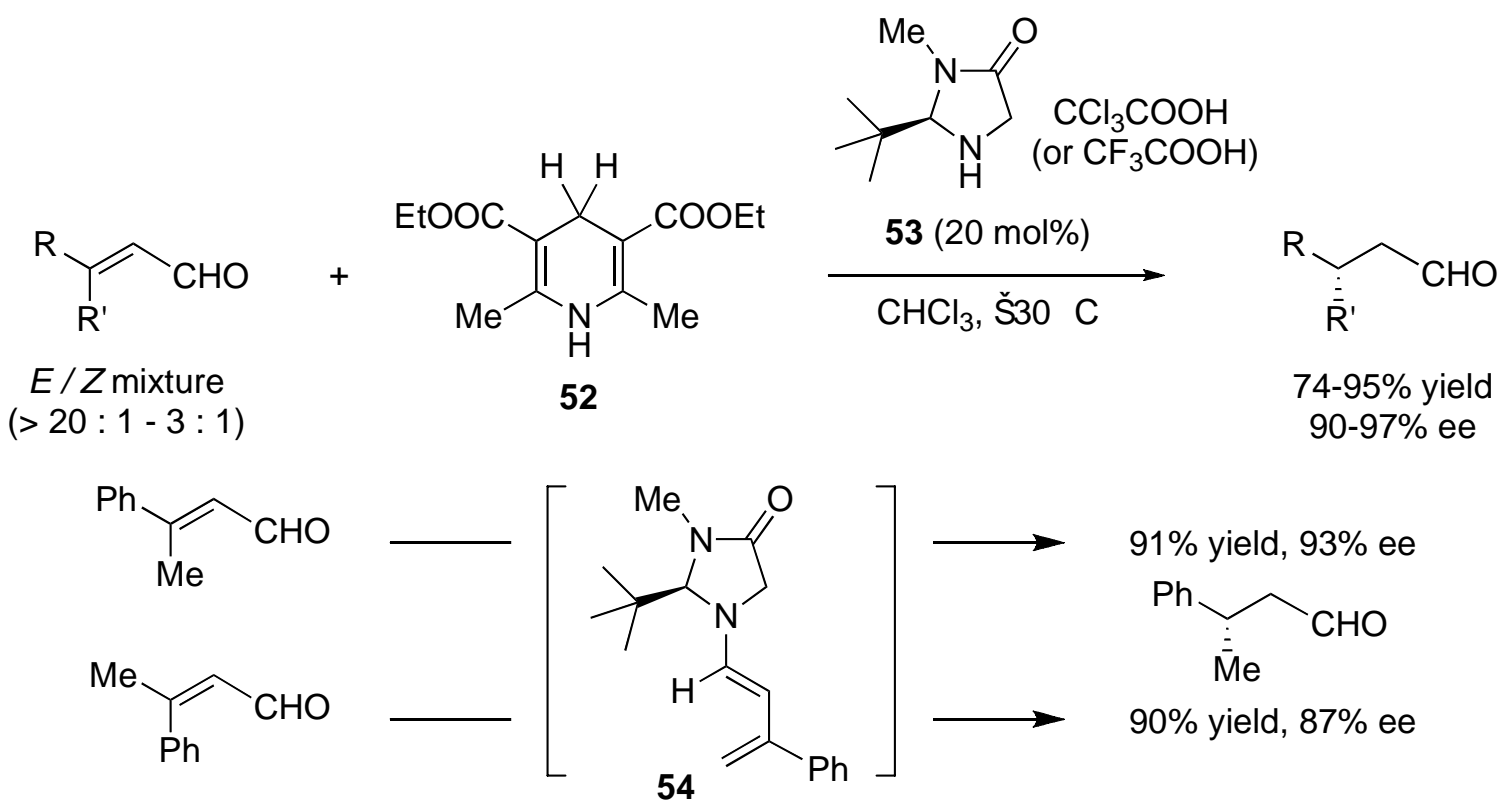

Scheme 53. Organocatalytic asymmetric reduction of $\alpha, \beta$-unsaturated aldehydes<smiles>[R]C([R])=Nc1ccccc1</smiles><smiles>O=C(c1ccccn1)N1CCCC1C(O)(c1ccccc1)c1ccccc1</smiles>

Ref. 176b: cat 55 (10 mol\%) in $\mathrm{CH}_{2} \mathrm{Cl}_{2}, 0 \mathrm{C}-\mathrm{rt}$ yield up to $90 \%$ ee up to $80 \%$<smiles>Cc1cc(C)cc(NC(=O)C(C(C)C)N(C)C(=O)C=O)c1</smiles>

56

Ref. 177a: cat 56 (10 mol\%) in $\mathrm{CHCl}_{3}$ or toluene, $\mathrm{rt}$ yield up to $95 \%$ ee up to $92 \%$<smiles>C[C@@H]1CN(C(=O)C(=O)Nc2ccccc2)CCN1S(=O)(=O)c1ccc(C(C)(C)C)cc1</smiles>

57

Ref. 178: cat 57 (10 mol\%) in $\mathrm{CH}_{2} \mathrm{Cl}_{2}, \mathrm{~S}_{20} \mathrm{C}$ yield up to $99 \%$ ee up to $97 \%$

Scheme 54. Organocatalytic asymmetric reduction of imines with trichlorosilane

The application of this strategy to carbonyl reduction has also been reported in the literature (Scheme 55). ${ }^{179,} 180$

For other related works on the use of proline or related compounds, only references are shown for convenience. $^{181,182}$ 


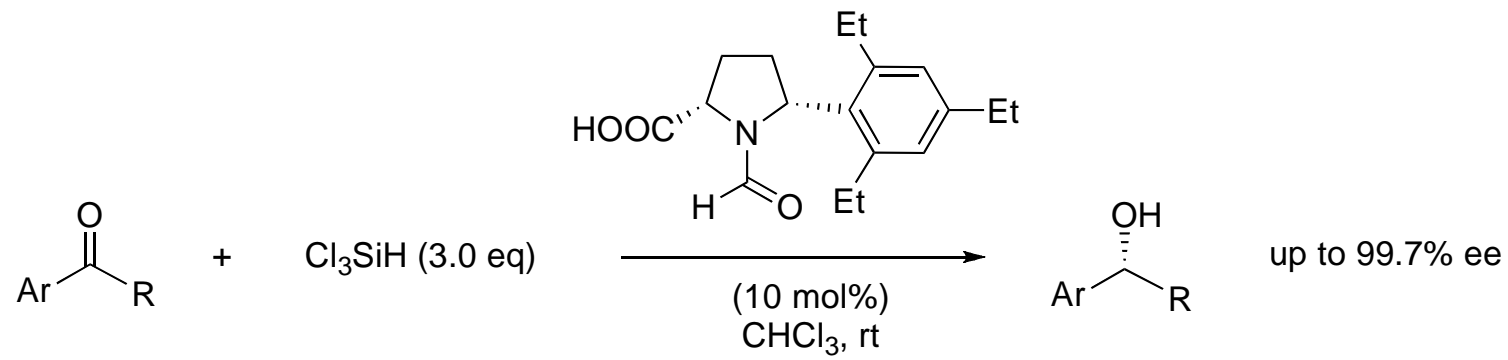

Scheme 55. Organocatalytic asymmetric reduction of ketones with trichlorosilane

\section{CONCLUSIONS}

As described above, a great deal of success has been achieved in a wide variety of asymmetric transformations using a series of proline and related organocatalyts. This fascinating field has grown rapidly since the beginning of this century.

Proline-based organocatalytic asymmetric synthesis offers several advantages over metal-catalyzed systems; for example, the ready availability of both enantiomers, ease of handling without the need for special equipment or inert atmosphere, and in some cases environment-friendly processes. Unfortunately, however, significant limitations still remain to be solved in this field; for example, high catalyst loading, long reaction period, and harmful organic solvent media. A proline-based chiral organocatalyst system proceeds under general acid catalysis that relies on relatively weak hydrogen-bonding between the catalysts and the substrates in the transition state. Even though such bonds are weak singly, it might be possible to make strong bonding by assembling them or by carefully tuning the action site as in enzyme systems.

We hope that from this exceedingly progressive field in modern organic chemistry a new, much more powerful catalyst as well as highly efficient organocatalyst-based asymmetric transformations can be developed in the near future.

\section{NOTE ADDED IN PROOF}

Recently, an important publication that describes the mechanistic investigation of proline-catalyzed asymmetric Michael and aldol reactions has appeared. (D. Seebach, A. K. Beck, D. M. Badine, M. Limbach, A. Eschenmoser, A. M. Treasurywala, R. Hobi, W. Prikoszovich, and B. Linder, Helv. Chim. Acta, 2007, 90, 425).

\section{ACKNOWLEDGEMENTS}

The authors would like to acknowledge the past and present members of our research group for their enthusiastic contributions in the field of organocatalysis. The authors also thank Prof. Y. Ichikawa and Dr. K. Nakano for their fruitful discussions and encouragement. Our research project in this field was supported 
by a Scientific Research on Priority Areas (18037053 \& 18032055) of MEXT, as well as by a Special Research Grant for Green Science from Kochi University. We also thank the Asahi Glass Foundation for financial support.

\section{REFERENCES}

1. Selected Reviews: a) H. Gröger and J. Wilken, Angew. Chem. Int. Ed., 2001, 40, 529. b) A. Córdova, Acc. Chem. Res., 2004, 37, 102. c) W. Notz, F. Tanaka, and C. F. Barbas III, Acc. Chem. Res., 2004, 37, 580. d) D. J. Ramón and M. Yus, Angew. Chem. Int. Ed., 2005, 44, 1602. e) M. M. B. Marques, Angew. Chem. Int. Ed., 2006, 45, 348.

2. a) B. List, J. Am. Chem. Soc., 2000, 122, 9336. b) B. List, P. Pojarliev, W. T. Biller, and H. J. Martin, J. Am. Chem. Soc., 2002, 124, 827. c) P. Pojarliev, W. T. Biller, H. J. Martin, and B. List, Synlett, 2003, 1903. d) J. W. Yang, M. Stadler, and B. List, Angew. Chem. Int. Ed., 2007, 46, 609.

3. S. Bahmanyar and K. N. Houk, Org. Lett., 2003, 5, 1249.

4. a) A. Córdova, W. Nozt, G. Zhong, J. M. Betancort, and C. F. Barbas III, J. Am. Chem. Soc., 2002, 124, 1842. b) A. Córdova, S. Watanabe, F. Tanaka, W. Nozt, and C. F. Barbas III, J. Am. Chem. Soc., 2002, 124, 1866. c) S. Watanabe, A. Córdova, F. Tanaka, and C. F. Barbas III, Org. Lett., 2002, 4, 4519. d) A. Córdova and C. F. Barbas III, Tetrahedron Lett., 2003, 44, 1923. e) W. Notz, F. Tanaka, S. Watanabe, N. S. Chowdari, J. M. Turner, R. Thayumanavan, and C. F. Barbas III, J. Org. Chem., 2003, 68, 9624. f) N. S. Chowdari, J. T. Suri, and C. F. Barbas III, Org. Lett., 2004, 6, 2507. g) W. Notz, S. Watanabe, N. S. Chowdari, G. Zhong, J. M. Betancort, F. Tanaka, and C. F. Barbas III, Adv. Synth. Catal., 2004, 346, 1131.

5. J. M. Janey, Y. Hsiao, and J. D. Armstrong III, J. Org. Chem., 2006, 71, 390.

6. a) A. Córdova, Synlett, 2003, 1651. b) A. Córdova, Chem. Eur. J., 2004, 10, 1987. c) I. Ibrahem and A. Córdova, Tetrahedron Lett., 2005, 46, 2839.

7. a) Y. Hayashi, W. Tsuboi, I. Ashimine, T. Urushima, M. Shoji, and K. Sakai, Angew. Chem. Int. Ed., 2003, 42, 3677. b) Y. Hayashi, T. Urushima, M. Shoji, T. Uchimaru, and I. Shiina, Adv. Synth. Catal., 2005, 347, 1595. c) Y. Hayashi, T. Urushima, M. Shin, and M. Shoji, Tetrahedron, 2005, 61, 11393.

8. a) A. Münch, B. Wendt, and M. Christmann, Synlett, 2004, 2751. b) K. Nagata, K. Nishimura, M. Yokoya, and T. Itoh, Heterocycles, 2006, 70, 335. c) T. Itoh, K. Nishimura, K. Nagata, and M. Yokoya, Synlett, 2006, 2207.

9. a) I. Ibrahem, J. Casas, and A. Córdova, Angew. Chem. Int. Ed., 2004, 43, 6528. b) I. Ibrahem and A. Córdova, Tetrahedron Lett., 2005, 46, 3363. c) I. Ibrahem, J. S. M. Samec, J. E. Bäckvall, and A. Córdova, Tetrahedron Lett., 2005, 46, 3965. d) H. Sundén, I. Ibrahem, L. Eriksson, and A. 
Córdova, Angew. Chem. Int. Ed., 2005, 44, 4877. e) I. Ibrahem, W. Zou, Y. Xu, and A. Córdova, Adv. Synth. Catal., 2006, 348, 211. f) I. Ibrahem, W. Zou, J. Casas, H. Sundén, and A. Córdova, Tetrahedron, 2006, 62, 357. g) W.-W. Liao, I. Ibrahem, and A. Córdova, Chem. Commun., 2006, 674. h) I. Ibrahem, P. Dziedzic, and A. Córdova, Synthesis, 2006, 4060.

10. a) T. Itoh, M. Yokoya, K. Miyauchi, K. Nagata, and A. Ohsawa, Org. Lett., 2003, 5, 4301. b) T. Itoh, M. Yokoya, K. Miyauchi, K. Nagata, and A. Ohsawa, Org. Lett., 2006, 8, 1533.

11. a) K. Funabiki, M. Nagamori, S. Goushi, and M. Matsui, Chem. Commun., 2004, 1928. b) M. Srinivasan, S. Perumal, and S. Selvaraj, ARKIVOC, 2005 (xi), 201. c) S. Fustero, D. Jiménez, J. F. Sanz-Cervera, M. Sánchez-Roselló, E. Esteban, and A. Simón-Fuentes, Org. Lett., 2005, 7, 3433. d) D. Enders, C. Grondal, M. Vrettou, and G. Raabe, Angew. Chem. Int. Ed., 2005, 44, 4079. e) D. Enders and M. Vrettou, Synthesis, 2006, 2155. f) D. Enders, C. Grondal, and M. Vrettou, Synthesis, 2006, 3597. g) A. S. Paraskar and A. Sudalai, Tetrahedron, 2006, 62, 5756.

12. Y. Hayashi, W. Tsuboi, M. Shoji, and N. Suzuki, J. Am. Chem. Soc., 2003, 125, 11208.

13. a) B. Westermann and C. Neuhaus, Angew. Chem. Int. Ed., 2005, 44, 4077. b) B. Rodríguez and C. Bolm, J. Org. Chem., 2006, 71, 2888. c) M. Hosseini, N. Stiasni, V. Barbieri, and C. O. Kappe, J. Org. Chem., 2007, 72, 1417.

14. M. L. Kantam, Ch. V. Rajasekhar, G. Gopikrishna, K. R. Reddy, and B. M. Choudary, Tetrahedron Lett., 2006, 47, 5965.

15. N. S. Chowdari, D. B. Ramachary, and C. F. Barbas III, Synlett, 2003, 1906.

16. M. Benaglia, M. Cinquini, F. Cozzi, A. Puglisi, and G. Celentano, Adv. Synth. Catal., 2002, 344, 533.

17. a) W. Notz, K. Sakthivel, T. Bui, G. Zhong, and C. F. Barbas III, Tetrahedron Lett., 2001, 42, 199. b) A. Córdova and C. F. Barbas III, Tetrahedron Lett., 2002, 43, 7749. c) P. H.-Y. Cheong, H. Zhang, R. Thayumanavan, F. Tanaka, K. N. Houk, and C. F. Barbas III, Org. Lett., 2006, 8, 811.

18. a) A. J. A. Cobb, D. M. Shaw, and S. V. Ley, Synlett, 2004, 558. b) A. J. A. Cobb, D. M. Shaw, D. A. Longbottom, J. B. Gold, and S. V. Ley, Org. Biomol. Chem., 2005, 3, 84.

19. N. S. Chowdari, M. Ahmad, K. Albertshofer, F. Tanaka, and C. F. Barbas III, Org. Lett., 2006, 8, 2839.

20. Y. Hayashi, J. Yamaguchi, K. Hibino, T. Sumiya, T. Urushima, M. Shouji, D. Hashizume, and H. Koshino, Adv. Synth. Catal., 2004, 346, 1435.

21. a) W. Zhuang, S. Saaby, and K. A. Jørgensen, Angew. Chem. Int. Ed., 2004, 43, 4476. b) J. Franzén, M. Marigo, D. Fielenbach, T. C. Wabnitz, A. Kjærsgaard, and K. A. Jørgensen, J. Am. Chem. Soc., 2005, 127, 18296. c) K. Frisch, A. Landa, S. Saaby, and K. A. Jørgensen, Angew. Chem. Int. Ed., 2005, 44, 6058. 
22. a) Y. Chi and S. H. Gellman, J. Am. Chem. Soc., 2006, 128, 6804. b) G.-L. Zhao and A. Córdova, Tetrahedron Lett., 2006, 47, 7417. c) I. Ibrahem, G.-L. Zhao, and A. Córdova, Chem. Eur. J., 2007, 13, 683 .

23. W. Wang, J. Wang, and H. Li, Tetrahedron Lett., 2004, 45, 7243.

24. A. Sasaoka, Md. Imam Uddin, A. Shimomoto, Y. Ichikawa, M. Shiro, and H. Kotsuki, Tetrahedron: Asymmetry, 2006, 17, 2963.

25. F. Zanardi, A. Sartori, C. Curti, L. Battistini, G. Rassu, G. Nicastro, and G. Casiraghi, J. Org. Chem., 2007, 72, 1814.

26. a) Y.-S. Wu, J. Cai, Z.-Y. Hu, and G.-X. Lin, Tetrahedron Lett., 2004, 45, 8949. b) I. Ibrahem, W. Zou, M. Engqvist, Y. Xu, and A. Córdova, Chem. Eur. J., 2005, 11, 7024.

27. a) T. Kano, Y. Yamaguchi, O. Tokuda, and K. Maruoka, J. Am. Chem. Soc., 2005, 127, 16408. b) T. Kano, Y. Hato, and K. Maruoka, Tetrahedron Lett., 2006, 47, 8467.

28. a) S. Mitsumori, H. Zhang, P. H.-Y. Cheong, K. N. Houz, F. Tanaka, and C. F. Barbas III, J. Am. Chem. Soc., 2006, 128, 1040. b) H. Zhang, M. Mifsud, F. Tanaka, and C. F. Barbas III, J. Am. Chem. Soc., 2006, 128, 9630. c) S. S. V. Ramasastry, H. Zhang, F. Tanaka, and C. F. Barbas III, J. Am. Chem. Soc., 2007, 129, 288.

29. I. Ibrahem and A. Córdova, Chem. Commun., 2006, 1760.

30. M. Mauksch, S. B. Tsogoeva, I. M. Martynova, and S. Wei, Angew. Chem. Int. Ed., 2007, 46, 393.

31. Reviews: a) O. M. Berner, L. Tedeschi, and D. Enders, Eur. J. Org. Chem., 2002, 1877. b) D. Almasi, D. A. Alonso, and C. Nájera, Tetrahedron: Asymmetry, 2007, 18, 299. c) S. B. Tsogoeva, Eur. J. Org. Chem., 2007, 1701.

32. a) M. Yamaguchi, T. Shiraishi, and M. Hirama, Angew. Chem., Int. Ed. Engl., 1993, 32, 1176. b) M. Yamaguchi, T. Shiraishi, Y. Igarashi, and M. Hirama. Tetrahedron Lett., 1994, 35, 8233. c) M. Yamaguchi, T. Shiraishi, and M. Hirama, J. Org. Chem., 1996, 61, 3520. d) M. Yamaguchi, Y. Igarashi, R. S. Reddy, T. Shiraishi, and M. Hirama, Tetrahedron, 1997, 53, 11223.

33. a) S. Hanessian and V. Pham, Org. Lett., 2000, 2, 2975. b) S. Hanessian, S. Govindan, and J. S. Warrier, Chirality, 2005, 17, 540. c) S. Hanessian, Z. Shao, and J. S. Warrier, Org. Lett., 2006, 8, 4787.

34. a) S. B. Tsogoeva, S. B. Jagtap, Z. A. Ardemasova, and V. N. Kalikhevich, Eur. J. Org. Chem., 2004, 4014. b) S. B. Tsogoeva, S. B. Jagtap, and Z. A. Ardemasova, Tetrahedron: Asymmetry, 2006, 17, 989.

35. S. B. Tsogoeva and S. B. Jagtap, Synlett, 2004, 2624.

36. D. Gryko, Tetrahedron: Asymmetry, 2005, 16, 1377.

37. P. Kotrusz and S. Toma, ARKIVOC, 2006 (v), 100. 
38. a) C. E. T. Mitchell, S. E. Brenner, and S. V. Ley, Chem. Commun., 2005, 5346. b) K. R. Knudsen, C. E. T. Mitchell, and S. V. Ley, Chem. Commun., 2006, 66. c) C. E. T. Mitchell, S. E. Brenner, J. García-Fortanet, and S. V. Ley, Org. Biomol. Chem., 2006, 4, 2039.

39. a) N. Halland, R. G. Hazell, and K. A. Jørgensen, J. Org. Chem., 2002, 67, 8331. b) N. Halland, P. S. Aburel, and K. A. Jørgensen, Angew. Chem. Int. Ed., 2003, 42, 661. c) N. Halland, T. Hansen, and K. A. Jørgensen, Angew. Chem. Int. Ed., 2003, 42, 4955.

40. A. Prieto, N. Halland, and K. A. Jørgensen, Org. Lett., 2005, 7, 3897.

41. a) S. P. Brown, N. C. Goodwin, and D. W. C. MacMillan, J. Am. Chem. Soc., 2003, 125, 1192. b) Y. Huang, A. M. Walji, C. H. Larsen, and D. W. C. MacMillan, J. Am. Chem. Soc., 2005, 127, 15051.

42. W. Wang, H. Li, and J. Wang, Org. Lett., 2005, 7, 1637.

43. J.-W. Xie, L. Yue, D. Xue, X.-L. Ma, Y.-C. Chen, Y. Wu, J. Zhu, and J.-G. Deng, Chem. Commun., 2006, 1563.

44. H. Gotoh, R. Masui, H. Ogino, M. Shoji, and Y. Hayashi, Angew. Chem. Int. Ed., 2006, 45, 6853.

45. a) J. Pulkkinen, P. S. Aburel, N. Halland, and K. A. Jørgensen, Adv. Synth. Catal., 2004, 346, 1077.

b) N. Halland, P. S. Aburel, and K. A. Jørgensen, Angew. Chem. Int. Ed., 2004, 43, 1272. c) M. Marigo, S. Bertelsen, A. Landa, and K. A. Jørgensen, J. Am. Chem. Soc., 2006, 128, 5475.

46. a) M. Marigo, T. Schulte, J. Franzén, and K. A. Jørgensen, J. Am. Chem. Soc., 2005, 127, 15710. b) I. Adamo, F. Benedetti, F. Berti, and P. Campaner, Org. Lett., 2006, 8, 51. c) M. Mečiarová, Ś. Toma, and P. Kotrusz, Org. Biomol. Chem., 2006, 4, 1420. d) D. B. Ramachary and R. Mondal, Tetrahedron Lett., 2006, 47, 7689. e) Y. K. Chen, M. Yoshida, and D. W. C. MacMillan, J. Am. Chem. Soc., 2006, 128, 9328. f) S. Bertelsen, P. Dinér, R. L. Johansen, and K. A. Jørgensen, J. Am. Chem. Soc., 2007, 129, 1536.

47. a) T. Govender, L. Hojabri, F. M. Moghaddam, and P. I. Arvidsson, Tetrahedron: Asymmetry, 2006, 17, 1763. b) W. Wang, H. Li, J. Wang, and L. Zu, J. Am. Chem. Soc., 2006, 128, 10354. c) R. Rios, H. Sundén, I. Ibrahem, G.-L. Zhao, L. Eriksson, and A. Córdova, Tetrahedron Lett., 2006, 47, 8547. d) R. Rios, H. Sundén, I. Ibrahem, G.-L. Zhao, and A. Córdova, Tetrahedron Lett., 2006, 47, 8679. e) H. Sundén, I. Ibrahem, G.-L. Zhao, L. Eriksson, and A. Córdova, Chem. Eur. J., 2007, 13, 574. f) H. Li, J. Wang, T. E-Nunu, L. Zu, W. Jiang, S. Wei, and W. Wang, Chem. Commun., $2007,507$.

48. a) S. Brandau, E. Maerten, and K. A. Jørgensen, J. Am. Chem. Soc., 2006, 128, 14986. b) H. Li, L. Zu, H. Xie, J. Wang, W. Jiang, and W. Wang, Org. Lett., 2007, 9, 1833.

49. B. List, P. Pojarliev, and H. J. Martin, Org. Lett., 2001, 3, 2423.

50. D. Enders and A. Seki, Synlett, 2002, 26. See also, B. M. Choudary, Ch. V. Rajasekhar, G. G. 
Krishna, and K. R. Reddy, Synth. Commun., 2007, 37, 91.

51. D. Terakado, M. Takano, and T. Oriyama, Chem. Lett., 2005, 34, 962.

52. a) P. Kotrusz, S. Toma, H.-G. Schmalz, and A. Adler, Eur. J. Org, Chem., 2004, 1577. b) M. S. Rasalkar, M. K. Potdar, S. S. Mohile, and M. M. Salunkhe, J. Mol. Catal. A: Chem., 2005, 235, 267.

53. a) H. J. Martin and B. List, Synlett, 2003, 1901. b) Y. Xu, W. Zou, H. Sundén, I. Ibrahem, and A. Córdova, Adv. Synth. Catal., 2006, 348, 418.

54. a) J. M. Betancort and C. F. Barbas III, Org. Lett., 2001, 3, 3737. b) J. M. Betancort, K. Sakthivel, R. Thayumanavan, and C. F. Barbas III, Tetrahedron Lett., 2001, 42, 4441. c) J. M. Betancort, K. Sakthivel, R. Thayumanavan, F. Tanaka, and C. F. Barbas III, Synthesis, 2004, 1509. d) N.Mase, R. Thayumanavan, F. Tanaka, and C. F. Barbas III, Org. Lett., 2004, 6, 2527.

55. H. Hagiwara, T. Okabe, T. Hoshi, and T. Suzuki, J. Mol. Catal. A: Chem., 2004, 214, 167.

56. a) A. Alexakis and O. Andrey, Org. Lett., 2002, 4, 3611. b) O. Andrey, A. Alexakis, and G. Bernardinelli, Org. Lett., 2003, 5, 2559. c) O. Andrey, A. Vidonne, and A. Alexakis, Tetrahedron Lett., 2003, 44, 7901. d) O. Andrey, A. Alexakis, A. Tomassini, and G. Bernardinelli, Adv. Synth. Catal., 2004, 346, 1147. e) S. Mossé and A. Alexakis, Org. Lett., 2005, 7, 4361. f) S. Mossé, M. Laars, K. Kriis, T. Kanger, and A. Alexakis, Org. Lett., 2006, 8, 2559. g) S. Mossé and A. Alexakis, Org. Lett., 2006, 8, 3577.

57. M.-K. Zhu, L.-F. Cun, A.-Q. Mi, Y.-Z. Jiang, and L.-Z. Gong, Tetrahedron: Asymmetry, 2006, 17, 491.

58. S. V. Pansare and K. Pandya, J. Am. Chem. Soc., 2006, 128, 9624.

59. a) P. Melchiorre and K. A. Jørgensen, J. Org. Chem., 2003, 68, 4151. b) Ref. 21b. c) S. Brandau, A. Landa, J. Franzén, M. Marigo, and K. A. Jørgensen, Angew. Chem. Int. Ed., 2006, 45, 4305.

60. a) Y. Chi and S. H. Gellman, Org. Lett., 2005, 7, 4253. b) Y. Hayashi, H. Gotoh, T. Hayashi, and M. Shoji, Angew. Chem. Int. Ed., 2005, 44, 4212. c) L. Zu, H. Li, J. Wang, X. Yu, and W. Wang, Tetrahedron Lett., 2006, 47, 5131. d) A. Lattanzi, Tetrahedron: Asymmetry, 2006, 17, 837. e) Y. Li, X.-Y. Liu, and G. Zhao, Tetrahedron: Asymmetry, 2006, 17, 2034. f) E. Reyes, J. L. Vicario, D. Badia, and L. Carrillo, Org. Lett., 2006, 8, 6135.

61. a) A. P. Brogan, T. J. Dickerson, and K. D. Janda, Angew. Chem. Int. Ed., 2006, 45, 8100. b) Y. Hayashi, Angew. Chem. Int. Ed., 2006, 45, 8103. c) D. G. Blackmond, A. Armstrong, V. Coombe, and A. Wells, Angew. Chem. Int. Ed., 2007, 46, 3798.

62. N. Mase, K. Watanabe, H. Yoda, K. Takebe, F. Tanaka, and C. F. Barbas III, J. Am. Chem. Soc., 2006, 128, 4966.

63. a) A. J. A. Cobb, D. A. Longbottom, D. M. Shaw, and S. V. Ley, Chem. Commun., 2004, 1808. b) 
Ref. 18b. c) C. E. T. Mitchell, A. J. A. Cobb, and S. V. Ley, Synlett, 2005, 611. d) M. Arnó, R. J. Zaragozá, and L. R. Domingo, Tetrahedron: Asymmetry, 2007, 18, 157.

64. a) Z.-Y. Yan, Y.-N. Niu, H.-L. Wei, L.-Y. Wu, Y.-B. Zhao, and Y.-M. Liang, Tetrahedron: Asymmetry, 2006, 17, 3288. b) S. Luo, H. Xu, X. Mi, J. Li, X. Zheng, and J.-P. Cheng, J. Org. Chem., 2006, 71, 9244.

65. T. Ishii, S. Fujioka, Y. Sekiguchi, and H. Kotsuki, J. Am. Chem. Soc., 2004, 126, 9558.

66. a) Y. Xu and A. Córdova, Chem. Commun., 2006, 460. b) D. Almasi, D. A. Alonso, and C. Nájera, Tetrahedron: Asymmetry, 2006, 17, 2064. c) C. Palomo, S. Vera, A. Mielgo, and E. Gómez-Bengoa, Angew. Chem. Int. Ed., 2006, 45, 5984.

67. a) W. Wang, J. Wang, and H. Li, Angew. Chem. Int. Ed., 2005, 44, 1369. b) J. Wang, H. Li, L. Zu, and W. Wang, Adv. Synth. Catal., 2006, 348, 425. c) J. Wang, H. Li, B. Lou, L. Zu, H. Guo, and W. Wang, Chem. Eur. J., 2006, 12, 4321. d) L. Zu, J. Wang, H. Li, and W. Wang, Org. Lett., 2006, 8, 3077. e) D. Enders and S. Chow, Eur. J. Org. Chem., 2006, 4578. f) D. Diez, M. J. Gil, R. F. Moro, I. S. Marcos, P. García, P. Basabe, N. M. Garrido, H. B. Broughton, and J. G. Urones, Tetrahedron, $2007,63,740$.

68. a) C.-L. Cao, M.-C. Ye, X.-L. Sun, and Y. Tang, Org. Lett., 2006, 8, 2901. b) Y.-J. Cao, H.-H. Lu, Y.-Y. Lai, L.-Q. Lu, and W.-J. Xiao, Synthesis, 2006, 3795. c) Y.-J. Cao, Y.-Y. Lai, X. Wang, Y.-J. Li, and W.-J. Xiao, Tetrahedron Lett., 2007, 48, 21. d) S. B. Tsogoeva and S. Wei, Chem. Commun., 2006, 1451. e) S. Wei, D. A. Yalalov, S. B. Tsogoeva, and S. Schmatz, Catalysis Today, 2007, 121, 151.

69. a) S. Luo, X. Mi, L. Zhang, S. Liu, H. Xu, and J.-P. Cheng, Angew. Chem. Int. Ed., 2006, 45, 3093. b) D. Xu, S. Luo, H. Yue, L. Wang, Y. Liu, and Z. Xu, Synlett, 2006, 2569. c) S. Luo, X. Mi, S. Liu, H. Xu, and J.-P. Cheng, Chem. Commun., 2006, 3687.

70. T. J. Peelen, Y. Chi, and S. H. Gellman, J. Am. Chem. Soc., 2005, 127, 11598.

71. a) D. Enders, M. R. M. Hüttl, C. Grondal, and G. Raabe, Nature, 2006, 441, 861. b) D. Enders, M. R. M. Hüttl, J. Runsink, G. Raabe, and B. Wendt, Angew. Chem. Int. Ed., 2007, 46, 467. c) D. Enders, A. A. Narine, T. R. Benninghaus, and G. Raabe, Synlett, 2007, 1667.

72. a) M. T. H. Fonseca and B. List, Angew. Chem. Int. Ed., 2004, 43, 3958. b) J. W. Yang, M. T. H. Fonseca, and B. List, J. Am. Chem. Soc., 2005, 127, 15036.

73. I. K. Mangion and D. W. C. MacMillan, J. Am. Chem. Soc., 2005, 127, 3696.

74. a) Y. Hayashi, H. Gotoh, T. Tamura, H. Yamaguchi, R. Masui, and M. Shoji, J. Am. Chem. Soc., 2005, 127, 16028. b) M. Kikuchi, T. Inagaki, and H. Nishiyama, Synlett, 2007, 1075.

75. Reviews: a) P. Merino and T. Tejero, Angew. Chem. Int. Ed., 2004, 43, 2995. b) H. Yamamoto and N. Momiyama, Chem. Commun., 2005, 3514. c) J. M. Janey, Angew. Chem. Int. Ed., 2005, 44, 
4292. d) M. Marigo and K. A. Jørgensen, Chem. Commun., 2006, 2001. e) G. Guillena and D. J. Ramón, Tetrahedron: Asymmetry, 2006, 17, 1465.

76. G. Zhong, Angew. Chem. Int. Ed., 2003, 42, 4247.

77. S. P. Brown, M. P. Brochu, C. J. Sinz, and D. W. C. MacMillan, J. Am. Chem. Soc., 2003, 125, 10808.

78. a) Y. Hayashi, J. Yamaguchi, K. Hibino, and M. Shoji, Tetrahedron Lett., 2003, 44, 8293. b) Y. Hayashi, J. Yamaguchi, T. Sumiya, and M. Shoji, Angew. Chem. Int. Ed., 2004, 43, 1112. c) Y. Hayashi, J. Yamaguchi, T. Sumiya, K. Hibino, and M. Shoji, J. Org. Chem., 2004, 69, 5966.

79. a) A. Bøgevig, H. Sundén, and A. Córdova, Angew. Chem. Int. Ed., 2004, 43, 1109. b) A. Córdova, H. Sundén, A. Bøgevig, M. Johansson, and F. Himo, Chem. Eur. J., 2004, 10, 3673. c) A. Córdova, H. Sundén, Y. Xu, I. Ibrahem, W. Zou, and M. Engqvist, Chem. Eur. J., 2006, 12, 5446.

80. a) S. P. Mathew, H. Iwamura, and D. G. Blackmond, Angew. Chem. Int. Ed., 2004, 43, 3317. b) H. Iwamura, D. H. Wells, Jr., S. P. Mathew, M. Klussmann, A. Armstrong, and D. G. Blackmond, J. Am. Chem. Soc., 2004, 126, 16312. c) S. P. Mathew, M. Klussmann, H. Iwamura, D. H. Wells, Jr., A. Armstrong, and D. G. Blackmond, Chem. Commun., 2006, 4291.

81. P. H.-Y. Cheong and K. N. Houk, J. Am. Chem. Soc., 2004, 126, 13912.

82. S.-G. Kim and T.-H. Park, Tetrahedron Lett., 2006, 47, 9067.

83. Y. Hayashi, J. Yamaguchi, K. Hibino, T. Sumiya, T. Urushima, M. Shoji, D. Hashizume, and H. Koshino, Adv. Synth. Catal., 2004, 346, 1435.

84. N. Momiyama, H. Torii, S. Saito, and H. Yamamoto, Proc. Natl. Acad. Sci., 2004, 101, 5374.

85. W. Wang, J. Wang, H. Li, and L. Liao, Tetrahedron Lett., 2004, 45, 7235.

86. H. Sundén, N. Dahlin, I. Ibrahem, H. Adolfsson, and A. Córdova, Tetrahedron Lett., 2005, 46, 3385 .

87. a) H.-M. Guo, L. Cheng, L.-F. Cun, L.-Z. Gong, A.-Q. Mi, and Y.-Z. Jiang, Chem. Commun., 2006, 429. b) H.-M. Guo, H.-Y. Niu, M.-X. Xue, Q.-X. Guo, L.-F. Cun, A.-Q. Mi, Y.-Z. Jiang, and J.-J. Wang, Green Chem., 2006, 8, 682.

88. K. Huang, Z.-Z. Huang, and X.-L. Li, J. Org. Chem., 2006, 71, 8320.

89. M. Engqvist, J. Casas, H. Sundén, I. Ibrahem, and A. Córdova, Tetrahedron Lett., 2005, 46, 2053.

90. a) H. Sundén, M. Engqvist, J. Casas, I. Ibrahem, and A. Córdova, Angew. Chem. Int. Ed., 2004, 43, 6532. b) A. Córdova, H. Sundén, M. Engqvist, I. Ibrahem, and J. Casas, J. Am. Chem. Soc., 2004, 126, 8914. c) I. Ibrahem, G.-L. Zhao, H. Sundén, and A. Córdova, Tetrahedron Lett., 2006, 47, 4659 .

91. a) D. B. Ramachary and C. F. Barbas III, Org. Lett., 2005, 7, 1577. b) J. Joseph, D. B. Ramachary, and E. D. Jemmis, Org. Biomol. Chem., 2006, 4, 2685. 
92. G. Zhong, Chem. Commun., 2004, 606.

93. S.-G. Kim, T.-H. Park, and B. J. Kim, Tetrahedron Lett., 2006, 47, 6369.

94. G. Zhong and Y. Yu, Org. Lett., 2004, 6, 1637.

95. a) S. Kumarn, D. M. Shaw, D. A. Longbottom, and S. V. Ley, Org. Lett., 2005, 7, 4189. b) S. Kumarn, D. M. Shaw, and S. V. Ley, Chem. Commun., 2006, 3211.

96. J. Yamaguchi, M. Toyoshima, M. Shoji, H. Kakeya, H. Osada, and Y. Hayashi, Angew. Chem. Int. Ed., 2006, 45, 789.

97. a) S. V. Narina and A. Sudalai, Tetrahedron Lett., 2006, 47, 6799. b) S. P. Kotkar and A. Sudalai, Tetrahedron Lett., 2006, 47, 6813.

98. a) Y. Yamamoto, N. Momiyama, and H. Yamamoto, J. Am. Chem. Soc., 2004, 126, 5962. b) N. Momiyama, Y. Yamamoto, and H. Yamamoto, J. Am. Chem. Soc., 2007, 129, 1190. See also Refs. 83 and 86.

99. Review: R. O. Duthaler, Angew. Chem. Int. Ed., 2003, 42, 975.

100. a) A. Bøgevig, K Juhl, N. Kumaragurubaran, W. Zhuang, and K. A. Jørgensen, Angew. Chem. Int. Ed., 2002, 41, 1790. b) N. Kumaragurubaran, K. Juhl, W. Zhuang, A. Bøgevig, and K. A. Jørgensen, J. Am. Chem. Soc., 2002, 124, 6254.

101. B. List, J. Am. Chem. Soc., 2002, 124, 5656.

102. S. Bertelsen, M. Marigo, S. Brandes, P. Dinér, and K. A. Jørgensen, J. Am. Chem. Soc., 2006, 128, 12973.

103. N. Dahlin, A. Bøgevig, and H. Adolfsson, Adv. Synth. Catal., 2004, 346, 1101.

104. N. S. Chowdari and C. F. Barbas III, Org. Lett., 2005, 7, 867.

105. C. Thomassigny, D. Prim, and C. Greck, Tetrahedron Lett., 2006, 47, 1117.

106. P. Kotrusz, S. Alemayehu, Š. Toma, H.-G. Schmalz, and A. Adler, Eur. J. Org. Chem., 2005, 4904.

107. a) H. Vogt, S. Vanderheiden, and S. Bräse, Chem. Commun., 2003, 2448. b) T. Baumann, H. Vogt, and S. Bräse, Eur. J. Org. Chem., 2007, 266.

108. J. T. Suri, D. D. Steiner, and C. F. Barbas III, Org. Lett., 2005, 7, 3885.

109. N. S. Chowdari, D. B. Ramachary, and C. F. Barbas III, Org. Lett., 2003, 5, 1685.

110. A. J. Oelke, S. Kumarn, D. A. Longbottom, and S. V. Ley, Synlett, 2006, 2548.

111. T. Kano, M. Ueda, J. Takai, and K. Maruoka, J. Am. Chem. Soc., 2006, 128, 6046.

112. H. Iwamura, S. P. Mathew, and D. G. Blackmond, J. Am. Chem. Soc., 2004, 126, 11770.

113. W. Wang, H. Li, J. Wang, and L. Liao, Tetrahedron Lett., 2004, 45, 8229.

114. a) W. Wang, J. Wang, and H. Li, Org. Lett., 2004, 6, 2817. b) J. Wang, H. Li, Y. Mei, B. Lou, D. Xu, D. Xie, H. Guo, and W. Wang, J. Org. Chem., 2005, 70, 5678. 
115. M. Marigo, T. C. Wabnitz, D. Fielenbach, and K. A. Jørgensen, Angew. Chem. Int. Ed., 2005, 44, 794.

116. Reviews: a) P. M. Pihko, Angew. Chem. Int. Ed., 2006, 45, 544. b) C. Bobbio and V. Gouverneur, Org. Biomol. Chem., 2006, 4, 2065.

117. D. Enders and M. R. M. Hüttl, Synlett, 2005, 991.

118. M. Marigo, D. Fielenbach, A. Braunton, A. Kjærsgaard, and K. A. Jørgensen, Angew. Chem. Int. Ed., 2005, 44, 3703.

119. D. D. Steiner, N. Mase, and C. F. Barbas III, Angew. Chem. Int. Ed., 2005, 44, 3706.

120. T. D. Beeson and D. W. C. MacMillan, J. Am. Chem. Soc., 2005, 127, 8826.

121. M. P. Brochu, S. P. Brown, and D. W. C. MacMillan, J. Am. Chem. Soc., 2004, 126, 4108.

122. a) N. Halland, A. Braunton, S. Bachmann, M. Marigo, and K. A. Jørgensen, J. Am. Chem. Soc., 2004, 126, 4790. b) N. Halland, M. A. Lie, A. Kjærsgaard, M. Marigo, B. Schiøtt, and K. A. Jørgensen, Chem. Eur. J., 2005, 11, 7083.

123. M. Marigo, S. Bachmann, N. Halland, A. Braunton, and K. A. Jørgensen, Angew. Chem. Int. Ed., $2004,43,5507$.

124. S. Bertelsen, N. Halland, S. Bachmann, M. Marigo, A. Braunton, and K. A. Jørgensen, Chem. Commun., 2005, 4821.

125. Review: G. Lelais and D. W. C. MacMillan, Aldrichimica Acta, 2006, 39, 79.

126. K. A. Ahrendt, C. J. Borths, and D. W. C. MacMillan, J. Am. Chem. Soc., 2000, 122, 4243.

127. A. B. Northrup and D. W. C. MacMillan, J. Am. Chem. Soc., 2002, 124, 2458.

128. R. Gordillo and K. N. Houk, J. Am. Chem. Soc., 2006, 128, 3543.

129. Q. Chu, W. Zhang, and D. P. Curran, Tetrahedron Lett., 2006, 47, 9287.

130. A. C. Kinsman and M. A. Kerr, J. Am. Chem. Soc., 2003, 125, 14120.

131. P. Wipf and X. Wang, Tetrahedron Lett., 2000, 41, 8747.

132. R. M. Wilson, W. S. Jen, and D. W. C. MacMillan, J. Am. Chem. Soc., 2005, 127, 11616.

133. R. M. de Figueiredo, M. Voith, R. Fröhlich, and M. Christmann, Synlett, 2007, 391.

134. a) R. Thayumanavan, B. Dhevalapally, K. Sakthivel, F. Tanaka, and C. F. Barbas III, Tetrahedron Lett., 2002, 43, 3817. b) D. B. Ramachary, N. S. Chowdari, and C. F. Barbas III, Tetrahedron Lett., $2002,43,6743$.

135. a) D. B. Ramachary, N. S. Chowdari, and C. F. Barbas III, Synlett, 2003, 1910. b) D. B Ramachary, N. S. Chowdari, and C. F. Barbas III, Angew. Chem. Int. Ed., 2003, 42, 4233. c) D. B. Ramachary, K. Anebouselvy, N. S. Chowdari, and C. F. Barbas III, J. Org. Chem., 2004, 69, 5838. d) D. B. Ramachary and C. F. Barbas III, Chem. Eur. J., 2004, 10, 5323.

136. a) K. Juhl and K. A. Jørgensen, Angew. Chem. Int. Ed., 2003, 42, 1498. b) T. C. Wabnitz, S. Saaby, 
and K. A. Jørgensen, Org. Biomol. Chem., 2004, 2, 828.

137. W. S. Jen, J. J. M. Wiener, and D. W. C. MacMillan, J. Am. Chem. Soc., 2000, 122, 9874.

138. a) S. Karlsson and H.-E. Högberg, Tetrahedron: Asymmetry, 2002, 13, 923. b) S. Karlsson and H.-E. Högberg, Eur. J. Org. Chem., 2003, 2782.

139. M. Harmata, S. Ghosh, X. Hong, S. Wacharasindhu, and P. Kirchhoefer, J. Am. Chem. Soc., 2003, $125,2058$.

140. a) A. I. Gerasyuto, R. P. Hsung, N. Sydorenko, and B. Slafer, J. Org. Chem., 2005, 70, 4248. b) B.-C. Hong, M.-F. Wu, H.-C. Tseng, and J.-H. Liao, Org. Lett., 2006, 8, 2217.

141. T. D. Beeson, A. Mastracchio, J.-B. Hong, K. Ashton, and D. W. C. MacMillan, Science, 2007, 316, 582 .

142. a) N. A. Paras and D. W. C. MacMillan, J. Am. Chem. Soc., 2001, 123, 4370. b) J. F. Austin and D. W. C. MacMillan, J. Am. Chem. Soc., 2002, 124, 1172. c) N. A. Paras and D. W. C. MacMillan, J. Am. Chem. Soc., 2002, 124, 7894.

143. R. Gordillo, J. Carter, and K. N. Houk, Adv. Synth. Catal., 2004, 346, 1175.

144. D. J. Denhart, R. J. Mattson, J. L. Ditta, and J. E. Macor, Tetrahedron Lett., 2004, 45, 3803.

145. P. Breistein, S. Karlsson, and E. Hedenström, Tetrahedron: Asymmetry, 2006, 17, 107.

146. a) B. F. Bonini, E. Capito, M. Comes-Franchini, M. Fochi, A. Ricci, and B. Zwanenburg, Tetrahedron: Asymmetry, 2006, 17, 3135. b) G. Bartoli, M. Bosco, A. Carlone, F. Pesciaioli, L. Sambri, and P. Melchiorre, Org. Lett., 2007, 9, 1403. c) C.-F. Li, H. Liu, J. Liao, Y.-J. Cao, X.-P. Liu, and W.-J. Xiao, Org. Lett., 2007, 9, 1847.

147. a) S. Saaby, P. Bayón, P. S. Aburel, and K. A. Jørgensen, J. Org. Chem., 2002, 67, 4352. b) K. A. Jørgensen, Synthesis, 2003, 1117.

148. J. F. Austin, S.-G. Kim, C. J. Sinz, W.-J. Xiao, and D. W. C. MacMillan, Proc. Natl. Acad. Sci., 2004, 101, 5482 .

149. M. Shi, J.-K. Jiang, and C.-Q. Li, Tetrahedron Lett., 2002, 43, 127.

150. a) J. E. Imbriglio, M. M. Vasbinder, and S. J. Miller, Org. Lett., 2003, 5, 3741. b) C. E. Aroyan, M. M. Vasbinder, and S. J. Miller, Org. Lett., 2005, 7, 3849. c) M. M. Vasbinder, J. E. Imbriglio, and S. J. Miller, Tetrahedron, 2006, 62, 11450.

151. H. Tang, G. Zhao, Z. Zhou, Q. Zhou, and C. Tang, Tetrahedron Lett., 2006, 47, 5717.

152. Y. Hayashi, T. Tamura, and M. Shoji, Adv. Synth. Catal., 2004, 346, 1106.

153. S.-H. Chen, B.-C. Hong, C.-F. Su, and S. Sarshar, Tetrahedron Lett., 2005, 46, 8899.

154. a) N. Vignola and B. List, J. Am. Chem. Soc., 2004, 126, 450. b) A. Fu, B. List, and W. Thiel, J. Org. Chem., 2006, 71, 320.

155. I. Ibrahem and A. Córdova, Angew. Chem. Int. Ed., 2006, 45, 1952. 
156. B. List and C. Castello, Synlett, 2001, 1687.

157. G. Sabitha, M. R. Kumar, M. S. Kumar Reddy, J. S. Yadav, K. V. S. Rama Krishna, and A. C. Kunwar, Tetrahedron Lett., 2005, 46, 1659.

158. V. Franckevicius, D. A. Longbottom, R. M. Turner, and S. V. Ley, Synthesis, 2006, 3215.

159. R. K. Kunz and D. W. C. MacMillan, J. Am. Chem. Soc., 2005, 127, 3240.

160. H. M. Hansen, D. A. Longbottom, and S. V. Ley, Chem. Commun., 2006, 4838.

161. J. F. Traverse, Y. Zhao, A. H. Hoveyda, and M. L. Snapper, Org. Lett., 2005, 7, 3151.

162. a) X. Liu, B. Qin, X. Zhou, B. He, and X. Feng, J. Am. Chem. Soc., 2005, 127, 12224. b) Y. Liu, X. Liu, J. Xin, and X. Feng, Synlett, 2006, 1085.

163. S. C. Pan, J. Zhou, and B. List, Synlett, 2006, 3275.

164. A. McNally, B. Evans, and M. J. Gaunt, Angew. Chem. Int. Ed., 2006, 45, 2116.

165. a) M. F. A. Adamo, V. K. Aggarwal, and M. A. Sage, J. Am. Chem. Soc., 2000, 122, 8317. b) V. K. Aggarwal, C. Lopin, and F. Sandrinelli, J. Am. Chem. Soc., 2003, 125, 7596. c) V. K. Aggarwal and G. Y. Fang, Chem. Commun., 2005, 3448.

166. a) W. Zhuang, M. Marigo, and K. A. Jørgensen, Org. Biomol. Chem., 2005, 3, 3883. b) M. Marigo, J. Franzén, T. B. Poulsen, W. Zhuang, and K. A. Jørgensen, J. Am. Chem. Soc., 2005, 127, 6964.

167. a) H. Sundén, I. Ibrahem, and A. Córdova, Tetrahedron Lett., 2006, 47, 99. b) G.-L. Zhao, P. Dziedzic, I. Ibrahem, and A. Córdova, Synlett, 2006, 3521.

168. a) A. Lattanzi, Adv. Synth. Catal., 2006, 348, 339. b) A. Lattanzi and A. Russo, Tetrahedron, 2006, 62, 12264.

169. a) X. Liu, Y. Li, G. Wang, Z. Chai, Y. Wu, and G. Zhao, Tetrahedron: Asymmetry, 2006, 17, 750. b) Y. Li, X. Liu, Y. Yang, and G. Zhao, J. Org. Chem., 2007, 72, 288.

170. S. Lee and D. W. C. MacMillan, Tetrahedron, 2006, 62, 11413.

171. Z. Bourhani and A. V. Malkov, Synlett, 2006, 3525.

172. a) F. Fache and O. Piva, Tetrahedron: Asymmetry, 2003, 14, 139. b) J. Le Bras and J. Muzart, Tetrahedron: Asymmetry, 2003, 14, 1911.

173. a) J. W. Yang, M. T. H. Fonseca, and B. List, Angew. Chem. Int. Ed., 2004, 43, 6660. b) J. W. Yang, M. T. H. Fonseca, N. Vignola, and B. List, Angew. Chem. Int. Ed., 2005, 44, 108. c) S. Mayer and B. List, Angew. Chem. Int. Ed., 2006, 45, 4193.

174. a) S. G. Ouellet, J. B. Tuttle, and D. W. C. MacMillan, J. Am. Chem. Soc., 2005, 127, 32. b) J. B. Tuttle, S. G. Ouellet, and D. W. C. MacMillan, J. Am. Chem. Soc., 2006, 128, 12662.

175. a) D. B. Ramachary, M. Kishor, and K. Ramakumar, Tetrahedron Lett., 2006, 47, 651. b) D. B. Ramachary, M. Kishor, and G. B. Reddy, Org. Biomol. Chem., 2006, 4, 1641.

176. a) F. Iwasaki, O. Onomura, K. Mishima, T. Kanematsu, T. Maki, and Y. Matsumura, Tetrahedron 
Lett., 2001, 42, 2525. b) O. Onomura, Y. Kouchi, F. Iwasaki, and Y. Matsumura, Tetrahedron Lett., $2006,47,3751$.

177. a) A. V. Malkov, A. Mariani, K. N. MacDougall, and P. Kocovsky, Org. Lett., 2004, 6, 2253. b) A. V. Malkov, S. Stoncius, K. N. MacDougall, A. Mariani, G. D. McGeoch, and P. Kocovsky, Tetrahedron, 2006, 62, 264.

178. Z. Wang, M. Cheng, P. Wu, S. Wei, and J. Sun, Org. Lett., 2006, 8, 3045.

179. Y. Matsumura, K. Ogura, Y. Kouchi, F. Iwasaki, and O. Onomura, Org. Lett., 2006, 8, 3789.

180. G. Wang, X. Liu, and G. Zhao, Synlett, 2006, 1150.

181. M. C. Angione and S. J. Miller, Tetrahedron, 2006, 62, 5254.

182. R. Varala, A. Nasreen, R. Enugala, and S. R. Adapa, Tetrahedron Lett., 2007, 48, 69. 